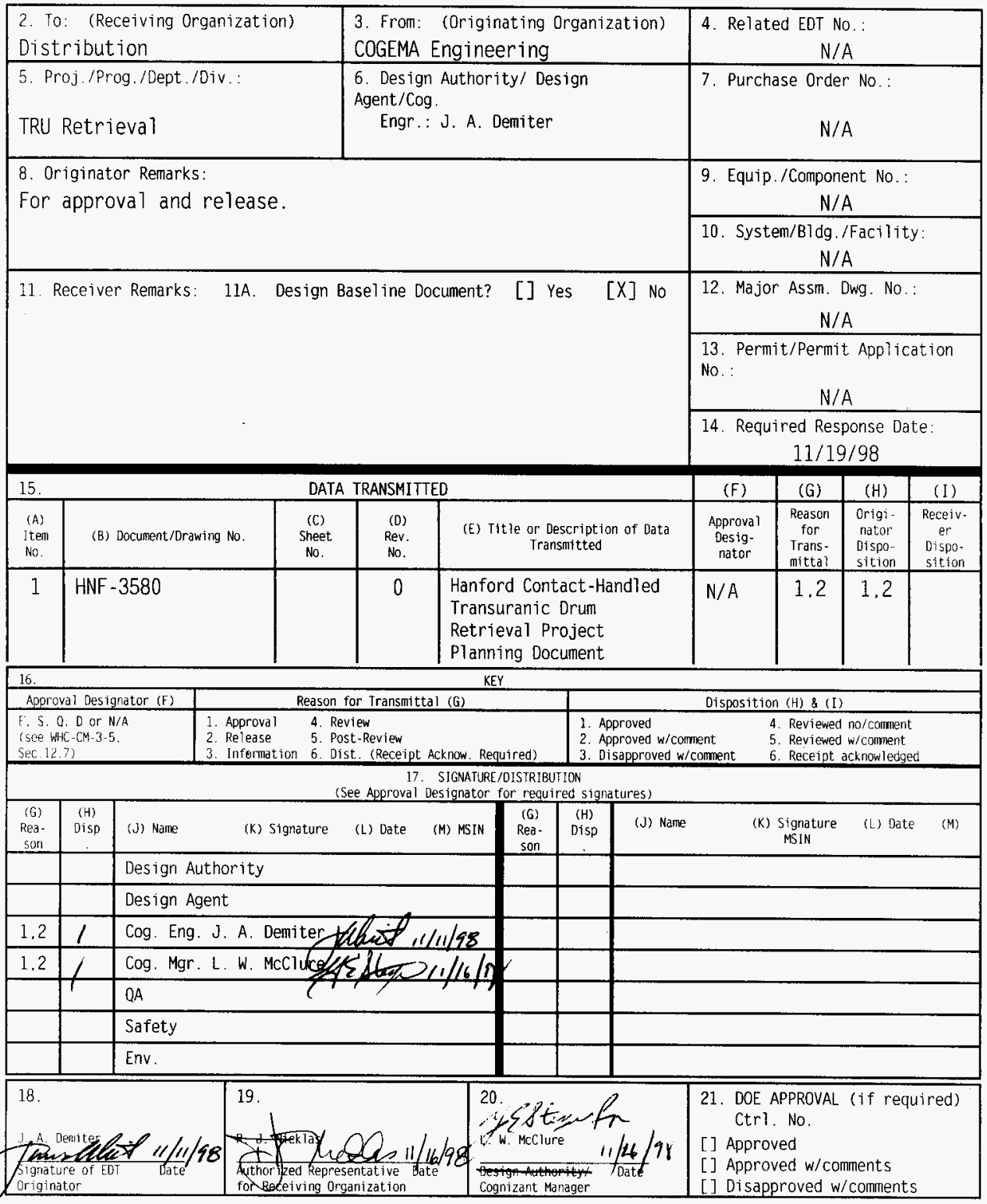




\section{HANFORD CONTACT-HANDLED TRANSURANIC DRUM RETRIEVAL PROJECT PLANNING DOCUMENT}

\section{J. A. Demiter}

COGEMA Engineering Corporation, Richland. WA 99352

U.S. Department of Energy Contract DE-AC06-96RL13200

EDT/ECN : 619521

Org Code: 32910

B\&R Code: EW3130020
UC: 510

CACN: 101594 COA: BA10

Total Pages: 53

Key Words: Contact Handled, Transuranic, Drum Retrieval, Planning

Abstract: The document presents the planning necessary to conduct the large-scale retrieval of $10,000 \mathrm{CH}$-TRU drums from Hanford 20-year retrievable storage.

TRADEMARK DISCLAIMER. Reference herein to any specific commercial product, process, or service by trade name. trademark, manufacturer. or otherwise, does not necessarily constitute or imply its endorsement, recommendation, or favoring by the United States Government or any agency thereof or its contractors or subcontractors

Printed in the United States of America. To obtain copies of this document. contact: Document Control Services. P. O. Box 950. Mailstop H6-08. Richland WA 99352. Phone (509) 372-2420: Fax (509) 376-4989.

Remin Aarded $11-17 \cdot 98$

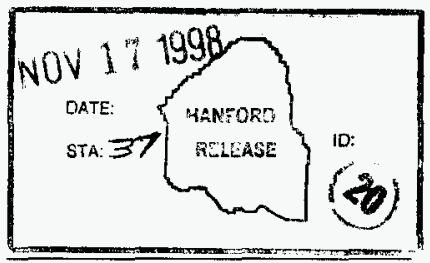

Release Stamp

\section{Approved for Public Release}




\section{CONTENTS}

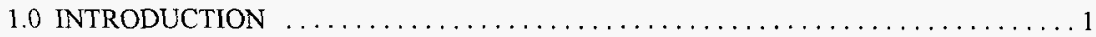

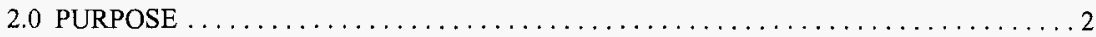

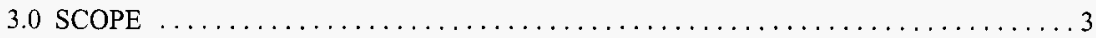

4.0 CH-TRU DRUM RETRIEVAL BACKGROUND $\ldots \ldots \ldots \ldots \ldots \ldots \ldots \ldots \ldots$

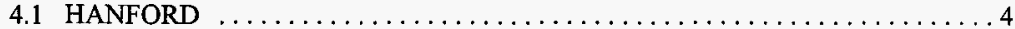

4.1.1 1982 20-year TRU Drum Retrievable Storage Inspection . . . . . . . 7

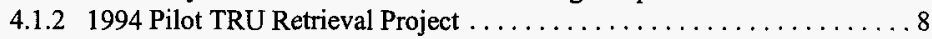

4.1.2.1 Background $\ldots \ldots \ldots \ldots \ldots \ldots \ldots \ldots \ldots \ldots \ldots \ldots, \ldots \ldots \ldots$

4.1.2.2 Development $\ldots \ldots \ldots \ldots \ldots \ldots \ldots \ldots \ldots \ldots \ldots, \ldots$

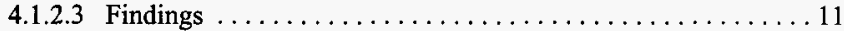

4.2 LOS ALAMOS NATIONAL LABORATORY $\ldots \ldots \ldots \ldots \ldots \ldots \ldots \ldots, \ldots \ldots$

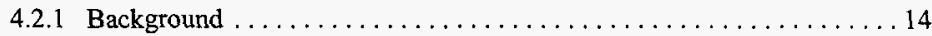

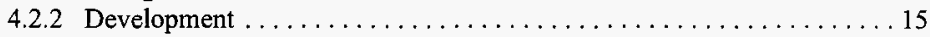

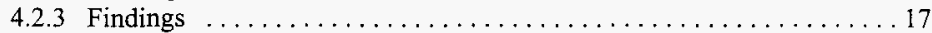

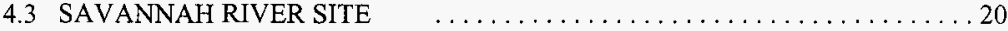

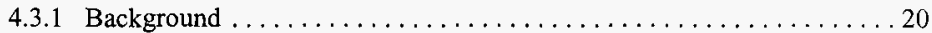

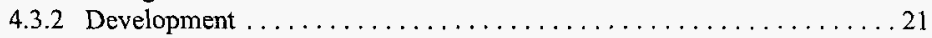

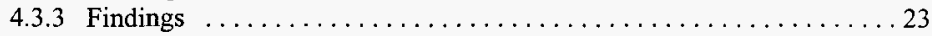

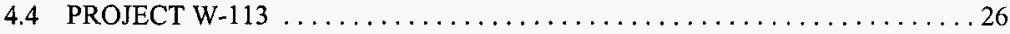

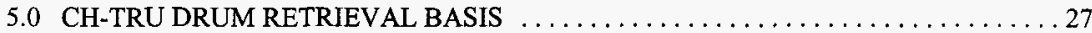

5.1 RETRIEVAL SITE SELECTION RATIONALE $\ldots \ldots \ldots \ldots \ldots \ldots \ldots \ldots 27$

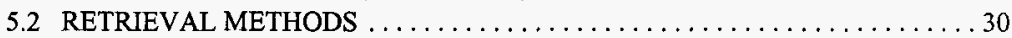

5.2.1 Drum Retrieval Using a Trench Cover Structure .............. 31

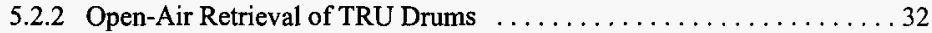

5.3 CH-TRU DRUM RETRIEVAL PROCESS FLOW $\ldots \ldots \ldots \ldots \ldots \ldots \ldots$

6.0 HANFORD CH-TRU DRUM RETRIEVAL NEEDS $\ldots \ldots \ldots \ldots \ldots \ldots \ldots \ldots \ldots$

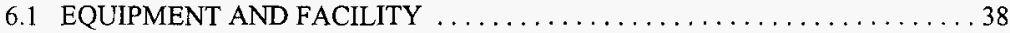

6.2 TRU DRUM RETRIEVAL TASKS $\ldots \ldots \ldots \ldots \ldots \ldots \ldots \ldots \ldots \ldots \ldots$

7.0 SCHEDULE, COSTS, AND MANPOWER LOADING $\ldots \ldots \ldots \ldots \ldots \ldots \ldots \ldots 42$

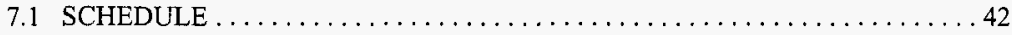

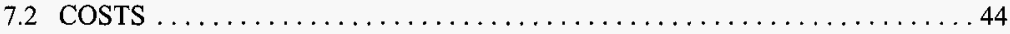

7.3 ROUGH ORDER OF MAGNITUDE COSTS $\ldots \ldots \ldots \ldots \ldots \ldots \ldots \ldots \ldots 45$

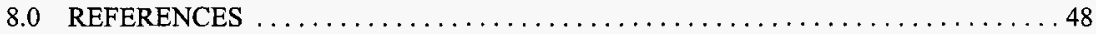




\section{Acronyms}

\begin{tabular}{|c|c|}
\hline AEC & Atomic Energy Commission \\
\hline CH-TRU & Contact-Handled Transuranic \\
\hline CVS & Container Venting System \\
\hline CWC & Central Waste Complex \\
\hline $\mathrm{CX}$ & Categorical Exclusion \\
\hline DNFSB & Defense Nuclear Facility Safety Board \\
\hline DOE & U.S. Department of Energy \\
\hline DOE-HQ & U.S. Department of Energy, Headquarters \\
\hline DVS & Drum Venting System \\
\hline FDC & Functional Design Criteria \\
\hline FRP & Fiberglass Reinforced Plywood \\
\hline GPR & Ground Penetrating Radar \\
\hline HEPA & High Efficiency Particle Air \\
\hline HFD & Hanford Fire Department \\
\hline HWOP & Hazardous Waste Operating Permit \\
\hline INEEL & Idaho National Engineering and Environmental Laboratory \\
\hline ISB & Interim Safety Basis \\
\hline ISPR & Independent Scientific Peer Review \\
\hline LANL & Los Alamos National Laboratory \\
\hline LEL & Lower Explosive Limit \\
\hline LLW & Low Level Waste \\
\hline NDE & Nondestructive Examination \\
\hline NEPA & National Environmental Policy Administration \\
\hline NFT & NFT, Incorporated \\
\hline NMED & New Mexico Environmental Department \\
\hline ORR & Operational Readiness Review \\
\hline PPE & Personal Protective Equipment \\
\hline RCRA & Resource Conservation and Recovery Act \\
\hline $\mathrm{RH}$ & Remote Handled \\
\hline RH-TRU & Remote Handled Transuranic \\
\hline RL & U.S. Department of Energy, Richland Operations Office \\
\hline ROM & Rough Order-of-Magnitude \\
\hline RTR & Real Time Radiography \\
\hline RUBB & RUBB, Incorporated \\
\hline SAR & Safety Analysis Report \\
\hline SARP & Safety Analysis Report for Packaging \\
\hline SRS & Savannah River Site \\
\hline SWITS & Solid Waste Information Tracking System \\
\hline TRU & Transuranic \\
\hline TWISP & Transuranic Waste Inspectable Storage Project \\
\hline USQD & Unresolved Safety Question Determinations \\
\hline
\end{tabular}


HNF-3580, Rev. 0

Acronyms (continued)

WAC Waste Acceptance Criteria

WAP Waste Acceptance Plan

WHC Westinghouse Hanford Company

WIPP Waste Isolation Pilot Plant

WRAP Waste Receiving and Processing Facility 
HNF-3580, Rev. 0

\subsection{INTRODUCTION}

The Hanford Site is one of several U. S. Department of Energy (DOE) sites throughout the United States that has generated and stored transuranic (TRU) wastes. The wastes were primarily placed in 55-gallon drums, stacked in trenches, and covered with soil. In 1970, the Nuclear Regulatory Commission ordered that TRU wastes be segregated from other radioactive wastes and placed in retrievable storage until such time that the waste could be sent to a geologic repository and permanently disposed. Retrievable storage also defined container storage life by specifying that a container must be retrievable as a contamination-free container for 20 years.

Hanford stored approximately 37,400 TRU containers in 20-year retrievable storage from 1970 to 1988 . The Hanford TRU wastes placed in 20-year retrievable storage are considered disposed under existing Resource Conservation and Recovery Act (RCRA) regulations since they were placed in storage prior to September 1988.

The majority of containers were 55-gallon drums, but 20-year retrievable storage includes several TRU wastes covered with soil in different storage methods:

1. Drums

- Drums stacked four to five high on asphalt pad trenches and divided into units called modules.

- Drums stacked five high in a concrete "V" bottom trench covered with a metal decking; approximately 1,300 drums were placed from 1972 through 1973.

- Drums placed horizontally in trenches; approximately 8,400 drums were placed from 1970 through 1972.

- Approximately 975 drums of classified waste, primarily in four trenches.

2. Boxes

- Approximately 600 boxes constructed of metal, fiberglass reinforced plywood (FRP), and concrete.

3. Other

- Remote-handled (RH) wastes, approximately 5,000 cubic feet.

- Miscellaneous containers including casks, double-drums, and equipment.

This document will outline the project to retrieve 10,000 contact-handled (CH) TRU drums stacked in trenches on asphalt pads. Approximately 26,200 drums are stacked in this manner. A subsequent document will present the plan to inspect and retrieve the remaining 20-year retrievably stored wastes including classified waste, $\mathrm{RH}$ waste, boxes, and horizontally stored drums. The document will also integrate Solid Waste facility [Waste Receiving and Processing 
(WRAP), Central Waste Complex (CWC), etc.] capabilities to receive, handle, and process the retrieved waste forms.

Retrieved drums will be assayed at the burial ground in a mobile assay unit to determine if the drums are TRU (greater than $100 \mathrm{nCi} / \mathrm{g}$ ). Drums that assay as low-level waste (LLW) will remain disposed in the burial ground.

Drums retrieved during this project will have the Solid Waste Information Tracking System (SWITS) records changed to reflect drum reclassifications and drum movements. All TRU drums will be moved to the CWC. The drums will eventually be moved to the WRAP facility where all opening, sorting, and characterization activities necessary to certify the TRU waste to Waste Isolation Pilot Plant (WIPP) Waste Acceptance Criteria (WAC) will be conducted.

Hanford Solid Waste Operations has sampled, inspected, and most recently (1994) retrieved a sample of drums from 20-year retrievable storage. The data gathered from these efforts (conducted over a 16-year period) collectively demonstrated the Hanford waste drums stored on asphalt pad trenches are still in a retrievable condition. Recent TRU drum and box retrieval projects (1997-98) conducted at the Los Alamos National Laboratory (LANL) and the Savannah River Site (SRS) have retrieved TRU waste containers stored 15 to 20 years from retrievable storage. The retrieved drums were in good condition and less than three percent required overpacking.

Large-scale TRU retrieval must start at Hanford while drums are in good condition to avoid criticality, handling, packaging, transportation, and contamination concerns. Hanford can also take advantage of LANL and SRS expertise developed during retrieval operations in the areas of planning, process flow, equipment types best suited to retrieval, documentation and procedure development, and operations personnel allocation and work scope.

To accomplish retrieval of TRU drums from retrievable storage and achieve DOE milestones (M-91-04 to initiate retrieval of 10,000 TRU drums and M-91-07 to complete the retrieval), the 10,000 TRU drum retrieval project was developed. The project planning will be based on information and data gathered from Hanford TRU drum retrieval and inspections, SRS and LANL drum retrieval, and data generated during the planning of the Hanford TRU Drum Retrieval Project W-113.

\subsection{PURPOSE}

The purpose of this document is to present the planning and methodology required to successfully complete the 10,000 TRU drum retrieval project at Hanford. To establish the planning methodology, information gathered from the Hanford Pilot TRU Drum Retrieval Project, planning data from Project W-113, and data gathered from ongoing TRU drum retrieval projects conducted at SRS and LANL will be presented.

The information provided in this document will focus on recent contact-handled transuranic ( $\mathrm{CH}$ TRU) retrieval activities and findings from 1994 to present. During this time period, TRU drum retrieval was conducted at three DOE site: SRS, LANL, and Hanford. The differing 
HNF-3580, Rev. 0

methodologies used in planning the retrieval projects, information gathered during the retrieval projects and the methods of operation will provide the basis for developing the Hanford 10,000 CH-TRU drum retrieval methodology.

Many cooperative TRU retrieval activities were conducted among these DOE sites during the late 1980 s and 1990 s to develop technologies, equipment, and documentation that would collectively become a major part of the final TRU retrieval projects. These technologies and concepts were freely shared among the three DOE sites in an effort to further TRU program development, provide needed data, or aid in developing equipment designs. As noteworthy as these developments were in furthering the DOE TRU program, they will not be presented in this document, except as they may apply to developing the methodology for planning the Hanford TRU drum retrieval project.

\subsection{SCOPE}

The scope of this Hanford 10,000 CH-TRU Drum Retrieval Project planning document is to:

1. Set the rationale for retrieved TRU drum selection from asphalt pad trenches.

2. Evaluate the Hanford 1994 Pilot TRU Retrieval Project and evaluate the project aspects for inclusion in this project plan.

3. Evaluate the data developed during the planning of the Hanford Project W-113 and assess the validity of the data for inclusion in the retrieval project plan.

4. Evaluate ongoing SRS and LANL TRU retrieval project activities for inclusion in the Hanford retrieval project plan.

5. Evaluate and recommend equipment and facilities needed for the project.

6. Recommend retrieval strategy and methodology.

7. Establish a project task list requiring closure prior to the project start.

8. Present a project schedule for completion of tasks to meet established milestones.

9. Present rough order-of-magnitude (ROM) cost estimates to close each task. (A comparative cost analysis cannot be conducted with other DOE sites. Specific cost data is not available from SRS and LANL at this time. A U.S. Department of Energy Headquarters (DOE-HQ) cost basis assessment must be completed at the two sites before TRU retrieval cost data will be released.)

The document will support the established TRU drum retrieval project initiation and completion milestones. A decrease in the project funding or schedule delay may jeopardize completion of the required tasks and established milestones. 
HNF-3580, Rev. 0

\subsection{CH-TRU DRUM RETRIEVAL BACKGROUND}

As an aid in comparing the various elements of TRU drum retrieval conducted at Hanford, SRS, and LANL, Table 4.1 has been developed. The table presents retrieval elements and indicates if the element was included within the retrieval scope of the particular site.

\subsection{HANFORD}

Hanford began segregation of TRU wastes in 1970 following the Atomic Energy Commission (AEC) Immediate Action Directive to segregate transuranium-bearing wastes from other radionuclides and place them in a storage condition that would be retrievable for 20 years as contamination-free packages. Wastes containing greater than 10 nanocuries transuranic material per gram of waste $(10 \mathrm{nCi} / \mathrm{g})$ were segregated as TRU wastes. The segregation was first imposed by facility. Any wastes generated from a TRU-designated facility were segregated as TRU at the burial grounds. Hanford compliance with the AEC order began in May 1970 by separating TRU wastes from other wastes that were placed in the same trench. The waste containers, mainly 55-gallon drums, were initially placed in the trench in a horizontal arrangement until the containers were within four feet of the trench surface. The waste containers were then covered with approximately four feet of soil and waste placements continued in this manner until the trench was full. Placement of waste containers and soil covering began at the west end of the trench and proceeded eastward.

The filled areas of the trench were driven over with subsequent waste shipping, disposal, and placement equipment. About 8,350 drums and other containers were disposed in this manner in four trenches from 1970 to 1972 in 200 East and 200 West Area trenches.

Trenches were then constructed specifically for disposal of TRU or LLW. A concrete "engineered V-Trench" was used for TRU waste storage during 1972 and 1973. The waste drums were stacked five high in a "V" formation until each cell was filled. The filled concrete cell was covered by a gable metal roof. After three cells were filled, this method was discontinued due to the high cost. The V-7 trench in burial ground $218-\mathrm{W}-4 \mathrm{~B}$ was the only location that this storage method was used. Approximately 1,340 drums were placed in the V-7 trench. 
HNF-3580, Rev. 0

TABLE 4.1

CH-TRU Retrieval Elements Evaluated For DOE Site Retrievals

\begin{tabular}{|c|c|c|c|c|}
\hline RETRIEVAL ELEMENT & $\begin{array}{l}\text { HANFORD } \\
1994 \text { PILOT }\end{array}$ & LANL & SRS & $\begin{array}{c}\text { HANFORD } \\
\text { 10,000 DRUM } \\
\text { PROPOSED }\end{array}$ \\
\hline Retrieval project had stand alone SAR & Yes & Yes & No & No \\
\hline $\begin{array}{l}\text { A retrieval dome structure was part of the } \\
\text { original design }\end{array}$ & No & Yes & Yes & No \\
\hline Retrieval dome included HEPA filtration & No & Yes & Yes* & No \\
\hline $\begin{array}{l}\text { Retrieval required PPE including mask and } \\
\text { "whites" use in dome }\end{array}$ & No & Yes & Yes* & No \\
\hline $\begin{array}{l}\text { Retrieval dome containment control at drum } \\
\text { retrieval face }\end{array}$ & No & No & Yes* & No \\
\hline $\begin{array}{l}\text { Retrieved drums were placed into 85-gallon } \\
\text { overpacks }\end{array}$ & No & $\begin{array}{l}\text { Yes* } \\
(50 \%)\end{array}$ & $\begin{array}{l}\text { Yes* } \\
(100 \%)\end{array}$ & No \\
\hline $\begin{array}{l}\text { Several large pieces of equipment were } \\
\text { required to conduct retrieval }\end{array}$ & Yes & Yes* & Yes* & No \\
\hline $\begin{array}{l}\text { Most recent retrieval conducted in open air } \\
\text { no cover structure }\end{array}$ & Yes & Yes & Yes & Yes \\
\hline NEPA documentation required a $\mathrm{CX}$ & Yes & Yes & Yes & Yes \\
\hline $\begin{array}{l}\text { Conducted exploratory drum inspections prior } \\
\text { to starting retrieval }\end{array}$ & Yes & Yes & Yes & No \\
\hline Retrieval sites included boxes & No & Yes & No & Yes \\
\hline Boxes were moved as part of retrieval project & NA & Yes & $\mathrm{NA}$ & Yes \\
\hline $\begin{array}{l}\text { Drums were vented prior to being placed in } \\
\text { storagc }\end{array}$ & Yes & No & No & $\begin{array}{c}\text { Yes } \\
\text { (Hanford Vent } \\
\text { Clip) }\end{array}$ \\
\hline $\begin{array}{l}\text { Drum venting is part of the retrieval project } \\
\text { scope }\end{array}$ & No & Yes & Yes & No \\
\hline GPR was used to detect drum surfaces & Yes & Yes & No & No \\
\hline Waste records exist for retrieved wastes & Yes & Yes & Yes & Yes \\
\hline $\begin{array}{l}\text { Pre-retrieval gas sampling conducted of stored } \\
\text { drums }\end{array}$ & Yes & Yes & No & Yes \\
\hline $\begin{array}{l}\text { Hazardous waste handling procedure } \\
\text { generated }\end{array}$ & Yes & Yes & Yes & Yes \\
\hline $\begin{array}{l}\text { TRU continuous air monitors in use during } \\
\text { retrieval }\end{array}$ & Yes & Yes & No & Yes \\
\hline
\end{tabular}


HNF-3580, Rev. 0

\begin{tabular}{|l|c|c|c|c|}
\hline \multicolumn{1}{|c|}{ RETRIEV AL ELEMENT } & $\begin{array}{c}\text { HANFORD } \\
\text { 1994 PILOT }\end{array}$ & LANL & SRS & $\begin{array}{c}\text { HANFORD } \\
\text { 10,000 DRUM } \\
\text { PROPOSED }\end{array}$ \\
\hline $\begin{array}{l}\text { Number of years that retrieved drums were } \\
\text { stored }\end{array}$ & 14 & 17 & 24 & 22 \\
\hline $\begin{array}{l}\text { Hazardous material monitoring during } \\
\text { retrieval }\end{array}$ & Yes & Yes & No & Yes \\
\hline $\begin{array}{l}\text { Transportation documentation bounded } \\
\text { retrieved drums, no new SARPS }\end{array}$ & No & Yes & Yes & No \\
\hline Training included extensive new training & Yes & Yes & No & No \\
\hline $\begin{array}{l}\text { Retrieved drum corrosion assessed by visual } \\
\text { inspection only }\end{array}$ & No & Yes & Yes & Yes \\
\hline $\begin{array}{l}\text { Drum head gas analysis was conducted as part } \\
\text { of retrieval }\end{array}$ & Yes** & Yes & Yes & No \\
\hline $\begin{array}{l}\text { Retrieval sites contained drums with 200 } \\
\text { plutonium, or above }\end{array}$ & Yes & Yes & No & Yes \\
\hline Drums were stacked four to five drums high & Yes & Yes & No & Yes \\
\hline $\begin{array}{l}\text { Drums were in earthen storage for 17 to 24 } \\
\text { years }\end{array}$ & No & Yes & Yes & Yes \\
\hline $\begin{array}{l}\text { Temporary support trailers placed to support } \\
\text { retrieval project }\end{array}$ & Yes & Yes & No & Yes \\
\hline $\begin{array}{l}\text { The retrieval project startup required an } \\
\text { Operational Readiness Review }\end{array}$ & Yes & No & No \\
\hline
\end{tabular}

* Requirement deleted prior to start of drum retrieval

**Conducted several months later

Subsequent to use of the V-7 trench, TRU trenches were constructed on a sloping asphalt pad. The drums and boxes were stacked, one on top of another, starting at the east end of the trench. Drums were usually stacked four high. Each layer was called a tier, with tier one being on the bottom. Between each tier, a layer of $1 / 4$-inch plywood was placed for stability. The drums were grouped into units called modules, which were 12 drums wide by 12 drums deep, by four or five drums high. The finished module was covered with a layer of $3 / 4$ inch plywood over which a heavy- gauge plastic tarp was placed. In this manner modules were separated from each other. The separation between modules may be a few inches or several feet. The modules were then covered with approximately four feet of soil.

From May 1970 through May 1988, Hanford placed approximately 37,400 containers in 20-year retrievable storage constituting approximately $524,000 \mathrm{ft}^{3}$. This total includes 975 drums of classified waste constituting approximately $7,200 \mathrm{ft}^{3}$, approximately 600 boxes constituting $248,000 \mathrm{ft}^{3}$ (47 percent of the total waste volume), and remote handled $(\mathrm{RH})$ waste constituting 
approximately $5,000 \mathrm{ft}^{3}$ (one percent of the total waste volume). The remainder of the waste was primarily contained in 55 -gallon drums.

The majority of stacked TRU containers is located in six trenches in the $218-\mathrm{W}-4 \mathrm{~B}$ and $218-\mathrm{W}-4 \mathrm{C}$ burial grounds. These trenches contain approximately 28,000 stored containers. Of these containers about 27,580 (98.5 percent) are drums and 350 are boxes or casks. ( 70 of the drums are designated as classified waste.) A selection of these containers (see Section 5.1) will be retrieved during the $10,000 \mathrm{CH}$-TRU drum retrieval project.

\subsubsection{20-year TRU Drum Retrievable Storage Inspection}

Hanford TRU drums, stored 8.5 years under soil cover, were uncovered and inspected in 1982 to determine the corrosion rate of drums placed in 20 -year TRU retrievable storage. The inspection was to provide data to determine if Hanford asphalt trench storage would meet the intent of the AEC 20-year retrievable storage. The project was completed successfully and presents data useful for planning the 10,000 TRU drum retrieval project.

The project uncovered and inspected drums placed in July 1973 (the drums were backfilled and covered with soil during September 1973) and uncovered in April of 1982. The drums were stacked in burial ground $218-\mathrm{W}-4 \mathrm{~B}$, module four, the first module to stack drums after discontinuing the " $\mathrm{V}$ " trench storage. The drums were stacked on the asphalt pad trench in the traditional module style. Plywood was placed between drum tiers and the module was covered with plywood and a reinforced plastic tarp.

During the course of the project, the following data were gathered about the drums stored in TRU retrievable storage:

1. No contamination (surface or airborne) was detected.

2. Prestart air samples taken through the module riser pipes did not detect hydrogen above background levels.

3. Initial module entry detected alpha contamination. Air samples were taken and decay time determined the presence of radon not alpha contamination.

4. Corrosion rates averaged $1 \mathrm{mil} /$ year at the drum/tarp interface.

5. Corrosion was undetectable for drums not in contact with the tarp covering.

The conclusion was that Hanford TRU retrievable storage would comply with the AEC directive requiring stored containers to meet the 20 -year storage criterion as retrievable, contaminationfree packages. The report made a recommendation that an inspection of another TRU drum module should be conducted in 1988 ( $3 / 4$ of the drum design life) to assess asphalt pad storage of TRU waste, determine if corrosion rates had remained the same or accelerated, and remove some of the inspected drums for further testing (Morton 1982). 
HNF-3580, Rev. 0

\subsubsection{Pilot TRU Retrieval Project}

\subsubsection{Background}

The Hanford 1994 TRU Drum Retrieval Project began development in 1988. The governing TRU program generated three main documents to define and bound the project. The first document (Anderson 1989a) defined the scope and developed a plan to provide the information and methodology required to work off the retrievable stored Hanford wastes. The document divided the program into three phases: Phase I, an existing records study; Phase II, a TRU drum retrieval and container inspection project that would include nondestructive examination (NDE) and nondestructive assay; and Phase III, a glovebox examination of the retrieved wastes to determine and characterize container contents.

The Phase I document (Anderson 1990) was completed in May 1988 and evaluated existing Hanford waste record data. The document created immediate controversy due to the redesignation and increase of Hanford remote handled transuranic (RH-TRU) waste totals by almost 600 percent to 5,000 cubic feet. This new total equaled the national DOE total for RHTRU waste. Previous documents had not recognized the RH-TRU waste in trenches and presented only RH-TRU volumes contained in caissons.

The Phase II document (Anderson 1989b) described 19 "sampling sites" selected to examine unique waste storage configurations and retrieve waste containers from among the entire inventory of Hanford stored TRU waste containers $(37,400)$. The selection of sampling sites was based on the waste storage configuration while the sample size was derived from statistical considerations. The program would provide the waste characterization data necessary to plan full-scale TRU retrieval at Hanford and information necessary to support WRAP facility design.

The development of the Phase II portion of the project was continually hampered by the various SAR-related issues discussed in Section 4.1.2.2. The characterization of conditions and waste containers at the 19 sampling sites was divided into two projects governed by two separate SARs. This division came about due to the increased potential of hydrogen in the unvented drums (although no technical data have been gathered to support this stand) and its effect on the frequency of drum explosions, resultant fire, and radionuclide release. One SAR was developed for vented drum inspection and retrieval (first five sites) while the unvented container inspection and retrieval, the remaining 14 sites, would be governed by a separate SAR. The vented drum SAR was the first of its kind and took five (5) years (1989 to 1993) to complete.

An initial Phase III document (Demiter 1988) was written in 1988 to identify facilities where a glovebox could be placed for waste container opening, waste sorting, and waste characterization. The document also identified available Hanford site gloveboxes. The program was discontinued in 1991 with the expectation that the WRAP project would handle all waste container opening, sorting, and characterization.

An additional focus of the program, originally conceived to support Phase II retrieval and inspection, was the development, fabrication, and testing of a container venting system. When Phase II was split into vented and unvented container retrieval/inspection in early 1990 , it became apparent that a container venting system would need to be developed to vent unvented containers (those without a Hanford vent clip) that were placed in 20 -year retrievable storage 
before 1978. The Container Venting System (CVS) was developed at Hanford to fulfill this purpose.

Hanford was the only DOE Site to vent drums (with the use of the Hanford developed vent clip)

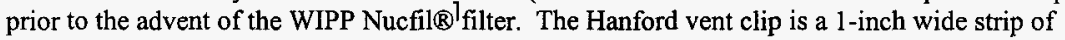
metal ( 26 gauge stainless steel) bent to fit over the drum so the lid gasket would be compressed and not make a complete seal to the drum when tightened in place. The gap in the lid gasket allows generated gases to escape the drum. No contamination has been recorded resulting from vent clip use.

Vent clip testing was initiated at Hanford in 1976 when it was discovered that drums containing the retrieved 216-Z-9 Crib soils were bulging due to radiolytic gas generation from the reaction between organic and moisture in the plutonium bearing soils. A maximum gas generation rate was derived from drum tests. A vent clip was designed that vented the maximum gas volume evolved during testing and exceeded the maximum gas generation rate by 900 percent (Ludowise 1978).

The vent clips were installed in all 216-Z-9 soil drums and began appearing in Hanford drums in approximately 1978 (no exact date has been found that required vent clips in drums). In addition to the vent clips, Engelhard Type D hydrogen/oxygen recombination catalyst packs were placed in the drums to combine generated hydrogen and oxygen into water vapor (Ludowise 1978).

No other venting devices were installed in SRS, LANL, INEEL, Lawrence Livermore National Laboratory, or Rocky Flats TRU drums until the WIPP filter was developed in 1985. Therefore, all SRS and LANL TRU drums being retrieved are unvented drums.

\subsubsection{Development}

Phase II vented drum retrieval (also know as The Pilot TRU Drum Retrieval Project) developed through many changes in a manner that seems somewhat convoluted to the outside observer. In an effort to satisfy all emerging documentation and maintain funding to complete the end goal (or as much as achievable), the project was directed into an extremely conservative posture. Consequently, the project costs were high, and the technical data gathered was only a portion of that expected from the original scope.

The SAR required for the project was given a low priority in a newly developing Safety organization. This was hampered by the fact that both the SAR development and solid waste environmental sections of the company were recently organized and had not set work priorities. Also at this time, new groups were being formed within the U.S. Department of Energy, Richland Operations Office (RL) and Westinghouse Hanford Company (WHC) that were to interpret, generate, and manage new regulations, which had varying RL, DOE-HQ, and WHC interpretations.

The SAR development section lacked staff to produce the vented-drum SAR; therefore, off-site personnel were contracted to produce the calculations, re-write, and defend the SAR to RL and DOE-HQ. The SAR was completed three years later and became the over-riding element of the vented TRU Drum Retrieval Project. Many restrictions were placed by the SAR that affected work methods and development. Ultimately, the Phase II project only retrieved drums from the

\footnotetext{
Nucfil is a registered trademark of 9

Nuclear Filter Technology, Inc.
} 
first two sampling sites, some of the most recent drums placed in the burial grounds between 1980 and 1982.

After completion of the SAR, the many other dependent activities of the project could proceed. Procedures, Hazardous Waste Operating Permit (HWOP), soil sampling plan, training plan, and many other draft documents were completed.

Training developed into a complex activity of emergency response, on the job training, and writing procedures. The training activity was also expanded to include mock-up training. A mock-up of a drum module was constructed and retrieval training was conducted step by step. In an effort to complete the mock-up training, steps were left out or done out of order. A correct critique of the mock-up training was never conducted with specific changes added to the procedure. As a result, the mock-up training was of little value.

Other parallel activities of the program continued, unaffected by the development of the SAR. These activities included:

- Hanford soils corrosion assessment conducted by placing metal coupons in Hanford soils for evaluation in later years.

- Development of retrieved container venting continued with fabrication and testing of the CVS.

- Ultrasonic equipment development deploying an NDE system in the field to inspect drum wall thickness and probe modules with a borescope at the retrieval sites.

- In situ inspection techniques by ground penetrating radar (GPR) to map the TRU burial ground trenches.

- Inter-site sharing of technologies, developments, and issues with other DOE sites.

The CVS was fabricated and factory acceptance testing was completed in April 1992. The CVS was shipped to Hanford and tested to the Operational Testing Procedure. A stop work order was issued to all Hanford work, except tank farms, due to decreased tank farm funding. The stop work delayed the start of CVS testing approximately nine months. The CVS finally completed operational testing in June 1993. The work delay allowed completion of the CVS explosivity testing by The Bureau of Mines. A subsequent document, Explosion Testing of the Container Venting System (Demiter 1993), supported the CVS design and drilling concept to vent drums.

Advanced infrared camera temperature measurements were used to quantify temperatures reached while drilling metal drum lid coupons and $1 / 4$-inch thick steel plate coupons (to simulate drilling boxes). Temperatures far below those required to ignite stoichiometric drum gas mixtures of hydrogen-air or methane-air were measured. The temperatures achieved during the testing were $365^{\circ} \mathrm{C}$ below the ignition point of a stoichiometric hydrogen-air gas mixture and $835^{\circ} \mathrm{C}$ below the ignition point of a methane-air stoichiometric gas mixture. 
HNF-3580, Rev. 0

Redirection of Phase II program activities to vented drum retrieval caused a cessation of all CVS work at the end of FY 1994. The CVS and all support equipment was shipped to the Hanford 2101M Building in FY 1995 for storage.

\subsubsection{Findings}

Although, TRU drum retrieval was conducted at only two of the retrieval sites, several findings were discovered concerning the condition of the drums stored in 20-year retrievable storage (Demiter 1994). The drums inspected and retrieved had been covered with a tarp and soil on an asphalt pad trench for approximately 14 years.

The findings at the retrieval and inspection of two separate TRU trench modules were the following:

1. The drum corrosion data were in direct correlation to earlier data gathered during the 1982 inspection (drums stored 8.5 years). Drum corrosion was the worst at the drum-tarp interface where condensate could form. But even at this interface the drum corrosion rate was found to be only one (1) mil per year. Corrosion within the module was negligible. The 55-gallon drums were estimated to have a life of 40 years in this storage configuration.

2. No radionuclide airborne contamination was found at either retrieval site. Air sampling conducted through the trench module riser pipes prior to drum retrieval found no airborne contamination.

3. No hazardous gases, including hydrogen, or materials were detected at the retrieval sites. This supported the pre-start gas sampling of the riser pipes.

4. There was no puddling of water in the drum modules from tarp condensate collection. The condition of the modules was dry and cool.

5. Soil sampling results indicated no soil contamination by radionuclides or hazardous materials.

6. The borescope was a valuable tool for inspecting and assessing conditions in the module. The borescope allowed inspection about half-way (six rows) into the module.

7. The ultrasonic testing provided drum wall thickness data for quantitative assessment of drum corrosion at the retrieval sites. The NDE testing was slow and costly. One drum was discovered to have a pin-hole and was overpacked. The small hole may have been the result of a pre-existing condition. It should be noted that the metal area around the hole was sound.

8. The SAR and subsequent operating procedures were too restrictive.

9. Removing soil with shovels to uncover drums is labor intensive and requires too much time. Mechanical means of uncovering drums is much preferred. 
10. The GPR activity conducted at the trenches to located drums under earth is far too inaccurate to recommend for further use.

11. A re-assay of retrieved drums was performed and compared to the 1978 assay values. Variance from original plutonium assay values from 1978 to the reassay taken in 1994 were $+42 \%$ to $-46 \%$ for drums containing 146 to 180 grams.

The Hanford Pilot TRU Drum Retrieval Project developed or used the following elements to fulfill part of the original scope of the program, which was "to provide the information and methodology required to work-off the waste retrievable stored at Hanford." The elements noted with an asterisk have applicable use for the 10,000 TRU Drum Retrieval Project:

1. The project specific SAR was written too conservatively thereby limiting the work scope that could be performed. The SAR was also a one-time use document. The SAR was too costly in terms of time, effort, and money.

2. The GPR used to assess distances to drums being retrieved gave poor results. Data gathered from GPR shows it to have negative field variance (gives distances that are much less than those actually measured in the field) ranging from -27 percent to -100 percent. The GPR was of little use in locating drums to be retrieved. Probing for drum tops and actual measurements of drums were the methods finally used.

3. NDE was performed as two services.

a. NDE ultrasonic drum wall measurements were slow, expensive, and demonstrated drum walls can be structurally sound even though the drum has a hole.

b. NDE inspection of the drum modules using a borescope was also conducted. The borescope video camera gave a good picture of stored drums and their condition several rows into the module. Use of a borescope would allow for the detection of a drum leak before the drum was exposed at the retrieval face. Early detection of poor condition drums would allow for planning to be conducted on how best to handle, sample, and move the drums.

4. A HWOP was developed to comply with the Health and Safety Plan regulations. The HWOP summarized information already contained in the Radiation Work Procedure, procedures, or other project documents.

5. National Environmental Policy Administration (NEPA) documentation was developed under a Categorical Exclusion (CX). The NEPA documentation bounds the retrieval activities of "vented drums." A review of the NEPA CX will be required to determine its validity for future operations: was it a one-time use activity, is the CH-TRU drum retrieval bounded under existing Solid Waste NEPA documentation, or will new NEPA documentation be required?

*6. A Soil Sampling Plan was developed to monitor for soil contamination (radiological, hazardous, and non-hazardous) at the first five drum retrieval sites. Chain of custody, qualified laboratory selection, assuring non-radioactive samples for off-site shipment, and 
meeting quality assurance requirements became issues for implementing the plan. The plan also developed an analytical procedure for random sampling. For the 10,000 TRU drum retrieval, a less intense soil sampling plan is needed that tests for dispersible radionuclides as trench soils are removed and trench surface conditions after drums are retrieved. Trench "release" criteria do not need to be established through the soil sampling plan.

7. The work procedures developed were too specific and limiting to the work tasks. Work procedures should be developed for work task control in a similar format and content as LANL Operating Procedures. The work procedures should control the work activities without being so specific as to hamper work steps.

*8. The transportation Safety Analysis Report for Packaging (SARP) for the 85-gallon drum overpack (Carlstrom 1995) and the transportation requirements for transporting retrieved 55-gallon drums, TRU drum limit, and TRU shipment limit (HNF-2209) will need to be assessed.

*9. The trench riser gas sampling conducted prior to TRU drum retrieval was a simple, inexpensive method of providing trench data. The riser sampling helps bound pre-start conditions and can provide hazardous/explosive gas and radionuclide information. The inspection may be coupled with borescope inspection to determine which risers are useable for data.

10. The Fire Protection Plan was part of the SAR and added some extreme fire control conditions that the Hanford Fire Department (HFD) could not comply with, due to lack of personnel or equipment. Any resultant fire at TRU drum retrieval should already be bounded under normal burial ground operations and invoke the "normal response" time for the arrival of fire fighting equipment. The 1994 TRU Drum Retrieval Project timed the HFD response time from the $200 \mathrm{~W}$ fire station and found it to be four (4) minutes, well under the 10 minutes indicated in the SAR.

*11. Supplemental continuous air monitoring units were placed during the project to measure any increase in radionuclide emissions beyond the background established for the burial grounds. The two units were placed east and northeast of the retrieval sites to assure downwind coverage. Although no increase in any radionuclides, above background, was detected by the new units, the units provide an increased measure of protection and advanced warning. The continuous air monitoring service should be incorporated into the 10,000 TRU Drum Retrieval Project.

*12. A mock-up of a drum module was used as part of the training for the 1994 Pilot TRU Drum Retrieval Project. The training of the retrieval staff for the 10,000 drum retrieval should include the removal of some of the uncovered drums at the west end of trenches 01,20 , or 29. The removal of these drums will simulate TRU drum retrieval utilizing the same personnel, retrieval equipment (Skytrak type vehicle), drum assay equipment, with the only difference being the removal of the soil covering of the trench. 
HNF-3580, Rev. 0

\subsection{LOS ALAMOS NATIONAL LABORATORY}

\subsubsection{Background}

LANL stored 16,600 drums in 20-year retrievable storage on TRU pads 1, 2, and 4 from 1970 to 1988. The drums were mainly 55 -gallon drums that had a rigid 90 -mil poly liner placed inside the drum. The top of the liner either snapped on or screwed on. The liner was to protect the inner surface of the drum from the waste form. The storage pads were ground-level storage on asphalt pads. Drums were stacked four and five high, usually surrounded by FRP boxes, and covered with 4 feet of earth. The covered TRU pads are therefore mounded above ground level differing from Hanford below grade asphalt pad storage.

LANL TRU storage pads are classified differently from those at Hanford. When the RCRA Part $A$ and interim Part B permits were submitted to the New Mexico Environmental Department (NMED) in 1988, the TRU 20-year retrievable storage pads were described as being active storage. Therefore, LANL retrievably stored drums and any associated activities to retrieve the drums after 1988 were governed by appropriate RCRA regulations.

In 1983 the TRU regional office identified a TRU waste sampling program for INEEL, LANL, and Rocky Flats. The program would provide information to the national TRU program for establishing WAC required for certification of TRU wastes for WIPP. LANL removed six drums from a storage shed and 12 drums from sealed metal storage casks (caissons). The drums were eight months to nine years old. Plutonium-239 gram loadings of the drums ranged from 0.1 to 198 grams. The drums were radiographed by RTR, drilled and gas sampled, opened and wastes sorted, reassayed for comparison with originals assays, and drum walls were measured using ultrasonics.

This sampling of LANL TRU drums indicated:

- Drum wall thickness measurements were near new drum criteria, little corrosion had taken place.

- All reassayed drums met the emerging WIPP WAC.

- No ${ }^{239} \mathrm{Pu}$ drums exhibited hazardous gas levels of concern but three eight-month old ${ }^{238} \mathrm{Pu}$ drums had hydrogen concentrations above lower explosive limit (LEL).

- RTR could not detect water in the drums.

As retrieval activities at DOE sites begin to increase during 1989, the LANL site indicated technology developed by other DOE sites would be applied for retrieving stored TRU wastes from Pads \#1, \#2, and \#4.

Hanford became the lead site in the development of drum venting and preparing documentation required to retrieve TRU drums. LANL followed retrieval advancements of other sites and developed a generic TRU program. In 1992, LANL decided to conduct a small sampling of TRU drums stored on Pad \#2. Sixteen (16) drums were retrieved in April 1992. One of the drums had a small pin-hole and was left at the site. In May 1992, NMED conducted an audit of LANL 
TRU pad storage and found the drum with a pin-hole that was not overpacked. NMED found several other violations to RCRA regulations and concluded that LANL was not governing its operations to RCRA and issued a Notice of Deficiency. The order fined LANL \$1.7 million for non-compliance to RCRA hazardous, confinement, and inspection requirements for "stored" TRU-mixed wastes.

LANL developed an action plan and schedule that outlined a program for compliance with RCRA. The LANL TRU retrieval program was placed under a Consent Order Agreement to comply with RCRA regulations and remove the 16,660 drums from TRU pads \#1, \#2, and \#4 within five years. This was later renegotiated to 10 years and the NMED fine was reduced to $\$ 750,000$.

The scheduled retrieval activities supported the following milestone completion dates:

- Retrieve 4,880 unvented drums and 161 FRP boxes from TRU Pad \#1 by September 30, 1998.

- Retrieve 4,540 unvented drums and 51 FRP boxes from TRU Pad \#4 by September 30, 2000.

- Retrieve 7,000 unvented drums from Pad \#2 by September 30, 2003.

The schedule also included milestones to wash and vent drums and place them in inspectible RCRA storage.

\subsubsection{Development}

The LANL TRU Retrieval Project was instituted as a new burial ground activity. The project did not take credit for or incorporate existing TRU documentation or activities (e.g., shipping, handling, or movement of TRU wastes) conducted within Technical Area 54 at LANL.

Therefore, the LANL TRU retrieval project development differed greatly from the SRS retrieval project.

LANL divided the TRU retrieval program into four construction phases and three retrieval phases. The TRU drum retrieval would be conducted under a "temporary" storage dome. The retrieval dome would be High Efficiency Particle Air (HEPA) filtered and pre-filtered to control dust. After soil removal, the retrieval process flow would follow these steps: (1) removal of the containers from the stacked array with a modified forklift, (2) overpacking drums as required, (3) shipment of the drums to drum cleaning and venting, (4) cleaning the drums, (5) drum venting, (6) RTR of drums at a mobile unit, and (7) placement of drums in storage domes. The project operations would be supported by safety, industrial hygiene, and health physics, in addition to the operations staff, to assure safe operations.

LANL planned enclosed retrieval within a 300-foot RUBB, Inc. (B) dome structure. The project anticipated retrieving drums that were in poor condition and projected that 50 percent of the retrieved drums would require overpacking. To overpack the retrieved drums from TRU Pad \#1, 2,000 85-gallon galvanized overpacks were procured.

After completion of Pad \#1 retrieval, the RUBB dome structure would be moved and set up at $\mathrm{Pad} \# 4$, then Pad \#2. The retrieved drums would be transported approximately $1 / 4 \mathrm{mile}$ to the 
venting facility, also a RUBB dome structure. Drum washing and venting would be conducted prior to shipment of the drums to a mobile RTR system. After completion of RTR, the drums would be placed in RCRA-inspectible drum storage arrays in dome structure (RUBB or sprung structure) buildings.

The overall project costs were developed at $\$ 43.5$ million over 10 years (the first year, FY 1993 , development funding was not included in this total). The funding was broken down as follows:

FY 1994 - $\$ 8.45$ million

FY 1995 - $\$ 3.45$ million

FY 1996 - \$2.75 million

FY 1997 - \$5.75 million

FY 1998 - \$3.58 million

FY 1999 - \$7.15 million

FY $2000-\$ 4.0$ million

FY 2001 - \$4.2 million

FY 2002 - \$4.1 million

In FY 1993, LANL also began development of drum venting equipment designs. LANL drum venting concerns paralleled those of SRS since both sites used a rigid 90-mil poly-liner in the drum. As the drums were vented, both the drum lid and poly-liner would need to be pierced to allow gas sampling and filter installation.

During FY 1991 and FY 1992, LANL had only shown distant interest in drum venting developments being conducted between SRS and Hanford. LANL did subsequently team with SRS to develop a filter-drill bit assembly for drilling the drum lid and 90-mil liner and removing a gas sample.

After the NMED Compliance Order was issued in 1993, LANL began serious development of a drum venting system. The Drum Venting System (DVS) was developed at LANL to provide for venting of retrieved drums. The DVS design incorporated several Hanford drum venting concepts (drum drilling, drum backcharge with nitrogen, evacuating the drum drill area, etc.) and other design concepts co-developed with SRS or Hanford. The DVS inter-site design reviews were conducted during FY 1994 with the 50 percent design review conducted in Jamuary 1994 and the final design review conducted in May 1994.

During the 1994 TRU Partnership Meeting, LANL reported that funding for FY 1995 was reduced and would delay or impact the following aspects of the LANL TRU retrieval project:

1. TRU retrieval waste analysis and characterization would have to rely on mobile equipment because funding was not available to construct facilities.

2. Construction of new TRU storage facilities would be delayed.

3. The Waste Acceptance Plan (WAP) submitted in 1994 was rejected by NMED and a Notice of Deficiency was issued by NMED. With limited funding, LANL could not resubmit the plan until March 1995. 
4. The majority of the DVS would be fabricated on site (at LANL) because of high bids and reduced funding. The reduced funding would slow fabrication of the DVS.

5. The entire TRU retrieval project would be delayed jeopardizing completion of NMED/DOE/LANL milestones for project completion in 10 years.

The DOE funding cuts for FY 1995 and subsequent project delay greatly disturbed NMED. The TRU retrieval project began negotiations with DOE to restore FY 1995 funding. LANL also received new management with a renewed focus on project completion. DOE funding was reestablished for the project, the WAP was approved, and the DVS was nearing completion by the close of FY 1995.

During FY 1996, LANL finished construction and installation of retrieval, venting, and storage domes. The DVS was completed and testing begun. Preparations were underway for the TWISP Operational Readiness Review (ORR) for the Category 2 storage buildings, retrieval, and venting.

The ORR generated several findings against the Category 2 storage and the DVS. Other findings were minor. The DVS lacked quality assurance in several fabrication and testing areas. The DVS would require another $\$ 500,000$ and six months to correct all the problems while the Category 2 storage buildings became a 13 -month trial to come to readiness.

During the ORR process LANL developed a very open, working relationship with DOE and NMED. LANL had an open-door policy for DOE, NMED, and the Defense Nuclear Facility Safety Board (DNFSB). Calls were made daily to the organizations of TWISP status, problems, and proposed solutions. In this manner, LANL developed a very trusted relationship with the agencies that still exists today.

LANL developed weekly meetings with management to update them on TWISP ORR progress. DOE and NMED were invited to these weekly meetings. LANL also developed weekly employee meetings where all progress, developments, or impacts of changes could be heard and assessed first hand. Using this approach, the TWISP developed a very cohesive working relationship. The success or failure of the project was transferred to the employees.

LANL finally demonstrated readiness in all phases of the TWISP project and began TRU retrieval from Pad \#1 on March 25, 1997.

\subsubsection{Findings}

LANL completed retrieval of TRU Pad \#1 on August 18, 1998 ahead of the September 30, 1998 milestone. The unvented drums and boxes stored on Pad \#1 were placed in storage from May 1979 through December 1984. Approximately 60 weeks of retrieval were required to retrieve the 4,880 drums and 161 boxes stored on the pad; this is a weekly retrieval average of 84 containers. The next TRU pad to be retrieved is Pad \#4. The milestone completion date is September 30, 2000. 
HNF-3580, Rev. 0

The findings of TRU Pad \#1 retrieval were:

1. No airborne contamination was found. LANL retrieved drums containing $>300$ grams plutonium.

2. The drums were in very good condition after being in earth-covered storage for 17 years. Only 126 of the 4,880 retrieved drums (less than three percent) required overpacking.

3. LANL demonstrated unvented drums could be retrieved and transported some distance (approximately $1 / 4$ mile from retrieval to venting) without incident.

4. No hazardous gases or materials were detected at retrieval.

5. Hydrogen, up to 26 percent, was detected in the unvented drums during the venting operation. The hydrogen could be safely purged from the drums using the DVS nitrogen purge cycle.

6. The DVS was able to vent drums at a rate 150 percent above the design requirement and vented 4,000 retrieved drums in 15 months. Because the DVS exceeded its drum venting design rate, another venting machine was not procured, which reduced project costs.

7. No criticality issues existed due to the good condition of the drums.

8. The drum corrosion inhibitor, applied to the drums prior to storage, worked very well. The inhibitor, an oil-base product, was easily cleaned by a non-hazardous, citrus-based cleaner.

9. The drum cleaning operation was able to use a spent personal protective equipment (PPE) waste stream for its supply of wipe rags. Therefore, drum cleaning did not generate a waste stream.

10. The stand alone SAR for the retrieval operations took too much time and effort to develop and defend. Its restrictively written style led to problems addressed in Item 18.

11. PPE (masks) may have been useful for eliminating dust from retrieval operations but were not required for radionuclide particulate filtration, since no airborne contamination was detected. Open-air retrieval will be conducted at Pads \#2 and \#4 without mask requirements. The dust problem will improve in open-air retrieval because the small dust particles can disperse.

12. LANL has found that about 90 percent of its retrieved drums are mixed waste.

13. The GPR conducted at the site, prior to retrieval, showed poor accuracy and was of little use. Probing was used to locate drums.

14. The Skytrak was an excellent choice for retrieval equipment. All vehicle attachments were used during retrieval: the forklift attachment, the front-end loader, bucket, the personnel basket, and the drum grabber. The vehicle extension provide a 30 -foot reach. 
15. Removing soil from atop the module was difficult in a dome structure (even though LANL removed about 2 feet of the soil overburden prior to placing the RUBB retrieval dome.) The structure inhibited free movement of the vehicle removing soil, vehicle emissions were a problem and had to be constantly monitored by an industrial hygienist, personnel work was restricted due to vehicle emissions, tailpipe or exhaust tubes to vent the exhaust outside were sometimes impractical for use, and a general safety problem was the result.

16. Several FRP boxes were ruptured or broken open. This was attributed to poor box design and inability of the boxes to withstand the soil loading. Perhaps boxes were damaged during handling and placement.

17. The loose material from breached containers did not spread contamination. Only 10 drums were required to repackage the loose material and locally contaminated soil from breached containers.

18. The SAR wording was too restrictive to the operation of retrieval. There were 24 unresolved safety question determinations (USQDs) written during the first year of operation due to violating the SAR wording. It was estimated that each USQD cost the project $\$ 50,000$.

LANL has already removed the 4-foot soil covering from TRU Pad \#4. The soil removal was made possible because no airborne radionuclide contamination or hazardous contamination was found at TRU Pad \#1 retrieval. The pad is covered with a tarp and retrieval activities will begin about October 15, 1998. The retrieval at this pad will be conducted in open air with no dome structure. PPE will be downgraded from whites and masks to whites only. Following completion of Pad \#4 work, retrieval will begin at Pad \# 2. Retrieval of \#2 containers will also be conducted in open air.

Several activities conducted during LANL retrieval can be applied to the Hanford 10,000 TRU drum retrieval project. These activities include the following:

1. Hanford retrieval should use versatile retrieval equipment, such as the Skytrak. Not only can the Skytrak retrieve drums with a drum grabber attachment but it can also (a) pick up boxes or plywood with its fork attachments; (b) remove soil from atop the stacked drums with the front-end loader attachment; (c) carry two employees in the personnel basket attachment to inspect drums, remove plywood, or remove soil from top tiers of stacked drums; and (d) maintain the $1.5 \mathrm{H}$ to $1.0 \mathrm{~V}$ required trench side-wall slope with the tilting front-end loader.

2. The development and review time of a project stand alone SAR make it difficult to complete in a timely manner. LANL found changes, in the form of USQDs, were very costly and time consuming. When LANL conducts open-air retrieval at TRU Pad \#2 several changes must be made to the retrieval concept outlined in the SAR.

3. The good condition of drums after 17 years in earthen storage support Hanford findings. The 10,000 drum retrieval will be retrieving drums stored for approximately that same time. The drum storage and soil conditions at the Hanford site and LANL are similar, with 
HNF-3580, Rev, 0

the exception that Hanford drums are below grade. Drum conditions at Hanford TRU drum retrieval should be similar to conditions encountered at LANL.

4. No airborne contamination was found from drums containing over 300 grams of plutonium. This finding supports data from previous Hanford TRU drum inspections and retrieval. The lack of contamination and findings of minimal drum corrosion support the open-air retrieval concept.

5. Drums stacked five high gave no additional problems for retrieval. Hanford has drums stacked five high in three modules of Trench 04 of the $218-\mathrm{W}-4 \mathrm{C}$ burial ground.

6. Open-air retrieval is the result of retrieval experience at LANL. Open-air retrieval is not expected to generate difficult problems. This supports Hanford's proposed approach to retrieval.

7. LANL developed a very open working relationship with the local DOE office, NMED, and the DNFSB.

8. LANL also developed a dedicated work team approach for the entire TWISP. Hanford should develop the team work concept and have the entire TRU retrieval team staffed early in the project.

9. Hanford should utilize LANL documentation developed during the TWISP project, as practical. The documentation may support several levels and areas required for the Hanford TRU retrieval project development.

10. PPE was not required for radionuclide protection. The full-face masks worn were more useful for protection from dust particulates. If dust becomes a concern at open-air retrieval, LANL will use canister masks not full-face masks. Hanford will need to evaluate dust generated and applicable dust control measures at TRU drum retrieval.

12. The drum venting experience from LANL indicates one venting machine can keep pace with retrieval needs. When unvented drums are retrieved at Hanford, the Hanford developed CVS should be evaluated for use and determination of drum venting rate.

More detailed information concerning the LANL TWISP project background, development, and findings may be obtained in the letter report COGEMA-98-879, dated October 8, 1998 (Demiter 1998).

\subsection{SAVANNAH RIVER SITE}

\subsubsection{Background}

SRS began segregating TRU wastes from other radioactive wastes in 1970 following the AEC order. The TRU wastes at SRS were further separated to less than 0.5 curie wastes being placed on TRU earthen pads and greater than 0.5 curie wastes being placed in metal culverts or caissons (called casks at LANL). This was done because most of the retrievably stored TRU wastes at 
SRS are ${ }^{238} \mathrm{Pu}$, unlike LANL and Hanford which have ${ }^{239} \mathrm{Pu}$ wastes. Like LANL, the SRS TRU drums stored on pads were unvented. SRS drums also had a rigid 90-mil poly-liner placed inside the drum. The poly-liner was in two part which either screwed together or snapped together. The liner was to provide additional protection to the drum inner surface from waste forms.

The practice of storing unvented TRU waste drums on earth-covered pads at SRS continued until 1985. After 1985, TRU drums were vented, with the WIPP Nucfilß filter, and placed outdoors on concrete Pads 7 through 13 . Over the years, the vented drums collected water through the vent filter. The drums were radiographed, dewatered, and removed to covered storage during the early 1990s.

The remaining 8,810 unvented drums under earthen cover on TRU Pads 2 through 6 became the focus of the SRS TRU program. Like LANL and Hanford, SRS had conducted several activities to assess the drum conditions. SRS had buried metal coupons early in the TRU program, so corrosion data was taken at intervals. Drums buried at the SRS site were expected to show accelerated corrosion due to the abundant rain fall and more acid type soil.

Between FY 1988 and FY 1994, SRS developed several programs focusing on remote handling, characterization, and processing retrieved wastes. SRS also worked with LANL to develop a lancet drill bit/filter assembly to drill through unvented drum lids and the 90 -mil poly-liners. The hollow lancet would also pull a drum head-gas and liner gas sample in the same manner as the Hanford CVS. When the TRU funding from DOE-HQ dropped in 1995, most of these programs ended.

\subsubsection{Development}

In late 1994, SRS began an aggressive TRU retrieval project that placed a milestone of January 19, 2000 to complete retrieval of the 8,810 unvented drums from the five TRU pads. SRS would conduct the project in phases and take credit for past TRU activity and operations conducted on the site. After 1.5 years of development, the final presentation and acceptance of the plan came in 1995 .

The SRS rationale presented for retrieval of the TRU drums were:

1. The TRU Waste Facility report for the retrieval of the 8,810 drums was written and approved. The conclusion of the report was that the TRU retrieval project should continue as outlined.

2. The venting and purging of 600 TRU unvented drums to gain data and test the NFT venting unit was proposed. The activity was evaluated as less than hazard Category 3. Meeting established design safety criteria, in conjunction with established SRS safety documentation, was justification that a Readiness Self Assessment or ORR would not be required.

3. An Independent Scientific Peer Review (ISPR) was conducted (discussed below).

4. The TRU Retrieval Project was incorporated into the Basis for Interim Operation. 
5. Meetings began with the State of South Carolina to (a) establish baseline soil sampling for site release and (b) provide a certified laboratory listing for soil analysis.

6. It was determined that a graded approach to DOE Order 5480.31 would be applied.

7. SRS established an "open door policy" for DOE and the State of South Carolina whereby the agencies could walk in and review documentation of the project at any time.

The SRS project indicated that most hazards of retrieval are already bounded by existing work conducted at the site. SRS contended that TRU retrieval held no unbounded or new hazards. Therefore, a graded approach would be used by SRS to approach each element of retrieval. SRS developed a criteria-weighted evaluation of all aspects of the project. To gain acceptance of the project approach and to dispel concerns posed by the SRS Citizens Advisory Board, SRS established a national ISPR to evaluate the project. The ISPR supported the SRS TRU retrieval project approach and concluded:

1. Treatment technologies to treat TRU wastes will not be available for 10 to 14 years.

2. The soil-covered drums are corroding and should be moved to safer storage.

3. Assessing the soil-covered drums now is a preventive measure that deals with the highest near-term safety concern at SRS.

4. The risk associated with retrieving and re-packaging the drums is well within the range of acceptable activities at SRS, which was directed at higher activity wastes beyond that found in the retrieval drums.

5. Therefore, the TRU waste drum retrieval project should proceed.

The SRS TRU project would encompass retrieval, venting, and subsequent storage of the TRU drums. The project would be conducted at the Solid Waste Management "E" Area facilities and use already existing TRU approved storage. After a successful venting demonstration to established criteria, the venting system would supply the needs of TRU retrieval. Following proof of the venting system, retrieval documentation would be written to define the mode of retrieval.

SRS acquired the services of NFT to supply the venting machine. NFT has developed a venting machine very similar to LANL and installed a HEPA filter train at the discharge. SRS installed the NFT venting machine in the sprung structure and began the venting test in March of 1996. The system performed to established operating and safety procedures. In December 1996, the venting of the 600 drums was complete.

SRS began development of the retrieval criteria and documentation in 1995. An alternative study outlined retrieval activities to be conducted. SRS received overview and recommendations to continue retrieval activities as defined in the study, including retrieval in a dome structure, use of HEPA ventilation for the facility, and use of an inner retrieval face containment. The project began procurement of required equipment for the retrieval of TRU drums. 
HNF-3580, Rev. 0

The ISPR completed its review of the TRU Retrieval Project in December 1995 and indicated that the retrieval of TRU drums was well within the bounds of normal burial ground operations. Normal operations were directed at higher activity wastes beyond that found in the retrieval drums.

After the ISPR review, the project began to set methodology to retrieve drums. The project submitted changes throughout 1995 to remove original design criteria. The removal of the design criteria was supported by:

1. Theoretical data were used to set original criteria. Recent activities had supplied actual data that would remove uncertainties.

2. Employee experience that removed many perceived safety scenarios.

3. Excess equipment that was the cause of several safety accident scenarios. The project would delete unneeded equipment and procure multi-use vehicles.

SRS supplied supportive documentation to demonstrate that some of the original design criteria were not needed and did not improve safety. In some cases, the added criteria actually worsened safety. The following retrieval criteria were removed in this process:

1. Several pieces of large retrieval equipment were deleted. The project would use one forklift with a front-end drum grabber to retrieve drums.

2. The criteria to overpack all retrieved drums was deleted. Retrieval of test drum coupons provided the actual data.

3. The inner retrieval face containment (environmental control) was removed. Safety accident frequencies were reduced based on hydrogen concentration found in the vented test drums and drum coupon corrosion data. The new data supported the removal of the inner containment control.

4. The dome HEPA filtration system removal was supported by actual data reported in Item 3 above.

5. The RUBB retrieval domes were also not required to supply a contamination control barrier.

Since SRS had already received the RUBB domes, HEPA filter systems, and the inner retrieval face containment system, a return of the products was not possible. Orders for several large pieces of equipment were canceled. The RUBB domes were installed over the first two TRU retrieval pads as weather covers only. The inner retrieval face containment system and HEPA filtration units were never installed or put in service.

\subsubsection{Findings}

SRS completed the management review of the TRU Retrieval Project in January 1997 and began retrieval of 1,934 unvented drums from TRU Pad 6 on January 22, 1997. Retrieval and venting 
of Pad $\# 6$ drums was completed on September 30,1997. Drums stored on the pad were placed prior to 1985. Retrieval of Pad \#4 (1,962 unvented drums) was completed on December 31, 1997 and retrieval of Pad 5 (2,357 unvented drums) was completed September 9, 1998. Drums stored on Pads 4 and 5 were placed in storage from 1975 through 1981. The remaining Pads \#3 and $\# 2$, containing drums placed in storage between 1970 and 1974 , will be completed far ahead of the scheduled milestone (January 19,2000). In total, SRS retrieved 6,253 drums in 20 months. All drums from the five storage sites are designated as TRU-mixed waste.

SRS retrieves 40 to 60 drums per work day (ten hour shift). There is only one retrieval and venting work shift per day. The retrieval crew is composed of four employees: two operators (one acting as a lead), one radiation monitor, and one heavy equipment operator.

SRS retained the original NFT venting machine following the test venting of 600 drums. The NFT venting machine was used to vent all retrieved drums until a second NFT machine was purchased and installed in June 1997. The two venting machines are able to keep pace with the SRS drum retrieval.

The findings of SRS TRU drum retrieval conducted at TRU Pads 1, 4, and 5 were the following:

1. Drums stored retrievably under earthen cover, for up to 24 years, were in very good condition. Only 16 of the 6,253 unvented TRU drums retrieved to date have required overpacking.

2. Unvented drums can be transported over a substantial distance (approximately $1 / 2$ mile from the SRS retrieval site to the venting building) without incident.

3. Unvented drums contain hydrogen in excess of the LEL. SRS found hydrogen concentration of 26 percent from the first retrieval site and report up to 60 percent in one waste stream at the last site.

4. No loose or airborne contamination was detected at retrieval. No PPE for radionuclide control were required.

5. One piece of retrieval equipment (forklift with drum grabber attachment) was required for stacked drum retrieval.

6. The small crew of four employees was able to exceed original retrieval goals by 100 percent.

7. No hazardous gases (including hydrogen) or materials were detected during retrieval at the three sites.

8. The concept of open-air retrieval of TRU drums can be conducted with a minimal stoppage due to weather.

9. Two drum venting machines were required to keep pace with SRS drum retrieval. 
10. It was agreed, that several original design criteria (HEPA filtration, overpacks, dome covering, retrieval face containment, extra large equipment), removed from the project as unnecessary, would have hindered completion of the project.

11. The controls placed on the project were sufficient to demonstrate that TRU drum retrieval, transportation, venting, and subsequent storage could be accomplished safely in an open-air atmosphere without jeopardizing any burial grounds operations standards.

12. A detailed soil sampling plan is only required if the retrieval site(s) requires a total release for site reuse.

Several of the activities conducted at SRS during the development and fulfillment of the TRU Drum Retrieval Project may be applied to the Hanford 10,000 TRU Drum Retrieval Project. Many of these activities support the LANL TWISP findings. Activities applicable to the Hanford TRU retrieval project include:

1. Open-air retrieval of TRU drums can be conducted within existing burial grounds operations limits.

2. One piece of retrieval equipment can fulfill drum retrieval needs. The equipment should be adaptable to retrieval site specific needs.

3. The condition of drums retrieved from a 20 to 25 -year storage under earthen cover is very good. Corrosion wall measurements do not need to be taken to confirm sound drum integrity.

4. Many of the methodology elements used to plan the SRS TRU retrieval project should be adopted by Hanford. The retrieval activities should be bounded under existing burial ground operations.

5. The retrieval operational mode and staff, including all retrieval equipment, should be tested as a part of training. The additional steps beyond those conducted during the training constitute new hazards. Hanford, like SRS, should have one new hazard - removal of soil from the modules.

6. PPE for retrieval operation required "blues" at SRS and no full-face or other cartridge masks.

7. Radiological work control (wind speed, temperature, and drum moisture) criteria are the same at SRS, LANL, and Hanford. Open-air retrieval has not been compromised by these criteria.

8. Open-air retrieval was the result of drum retrieval at SRS when technology and experience were applied. Much like LANL, SRS has not found, nor does it expect, open-air retrieval to generate difficult problems. 
More detailed information concerning the SRS TRU Retrieval Project background, development, and findings may be obtained from the letter report SESC-97-259, dated June 6, 1997 (Demiter 1997).

\subsection{PROJECT W-113}

Project W-113 was conceived to provide the first large-scale retrieval of containers from 20-year retrievable storage at Hanford. Concepts of the project go back to the early 1980 s when existing Hanford facilities were being evaluated for the inclusion of WRAP. Retrieval site methodology, container evaluation technologies, and drum waste and gas contents evaluation were being developed to support the newly emerging WIPP WAC.

Project W-113 Functional Design Criteria (FDC) with the document was written in 1989 and was later downsized into Phase I (one trench retrieval) with the completion of the one-trench FDC in 1993. The project was to provide equipment and facilities to retrieve TRU wastes stored under earthen cover from Trench 04 of the $218-\mathrm{W}-4 \mathrm{C}$ burial ground. The project was moved from Solid Waste Technology to Projects in 1990.

Trench 04 was the only TRU asphalt pad trench that was completely covered with soil and contained a sufficient number of containers ( 9,960 containers, 9,865 being 55 -gallon drums) to prove the W-113 retrieval concept by removing a substantial number of drums from storage. (Trench 04 contains approximately 38 percent of the drums stacked in asphalt pad trenches at Hanford.) The project had milestones set for the number of containers to be retrieved from Trench 04 . Therefore, the 10,000 drum figure began appearing in the milestone listing.

The 10,000 drum retrieval project, the subject of this document, inherited the drum retrieval milestone of Project W-113. Section 5.1 sets the retrieval site selection rationale for the 10,000 drum retrieval project. The project is committed to the retrieval of the 10,000 drums as inferred in the M-91-04 milestone.

The final W-113 Project, with reduced facilities, was valued at over \$38 million in 1994. The project included:

1. A retrieval structure that would be moved down the trench as retrieval progressed. The structure included HEPA filtration, airlocks, and foundations.

2. Drum venting and gas sampling system within the retrieval structure.

3. Mobile RTR system within the retrieval structure.

4. Mobile assay system within the retrieval structure.

5. Box overpack system within the retrieval structure.

6. Support buildings consisting of (a) an office building and (b) change room building.

7. Heavy equipment (cranes, forklifts) within the retrieval facility. 
8. Developing waste characterization data from waste records to assess requirements for criticality assessments and planning retrieval operations.

9. A drum retrieval rate of 16 drum per eight-hour shift.

The W-113 Project was terminated in 1995. The causes of terminating the project were: lack of DOE funding nation wide in FY 1995, the high cost of the project (at a time when WRAP was being constructed), and uncertain direction from $\mathrm{DOE}$ as to the course to take for stored TRU retrieval.

The 10,000 CH-TRU Drum Retrieval Project plans to take advantage of previously conducted work activities in developing the methodology for retrieval. Certainly elements of the SRS and LANL TRU retrieval projects will be used in the development of the 10,000 TRU Drum Retrieval Project at Hanford. Work activities developed under Project W-113 that will be useable for the 10,000 TRU drum retrieval are (a) the waste characterization data, and (b) the specification for the procurement of a mobile assay system.

\subsection{CH-TRU DRUM RETRIEVAL BASIS}

\subsection{RETRIEVAL SITE SELECTION RATIONALE}

Selection of the trench(es) for CH-TRU drum retrieval is based on several factors. Previous documents generated during the 1994 Pilot TRU Retrieval Project and Project W-113 provide all available data to assist in retrieval site selections. The methodology for site selection will be based on the following requirements:

1. Are the drums located on asphalt pads in stacked modules?

2. Are the drums vented and were the drums placed in retrievable storage after vent clip installation was required, approximately $1978 / 1979$ ?

3. Does the site contain a minimum number of boxes and "other" containers that will be unretrievable during this project? Large numbers of these other containers will cause movement and storage of large or awkward containers at the retrieval trench.

4. Does the retrieval site contain any waste forms that will be difficult to bound in the Master SAR or Interim Safety Basis (ISB)?

5. Have previous drum inspection or drum retrieval been conducted at the site to provide data on drum and site conditions?

6. Are the boxes in the selected site other than metal or FRP or of a size or weight making them difficult to move easily with available equipment?

7. Are there any RH-TRU or classified wastes in the retrieval site selected?

8. Will the drum storage dates bound drums placed in several other trenches? 
9. Is there any historical data supportive to site selection, i.e., well documented photographic history?

10. Are drum location mappings as complete as possible for the selected site?

The approximate number of drums stored in trenches compatible with Requirements 1 and 2 above are given below in descending order. Also noted are the bounding dates for drum placements in the trenches:

- 218-W-4C, Trench 04 - 9,865 drums (drums placed April 24, 1978 to October 29, 1984).

- *218-W-4C, Trench 01 - 5,080 drums (drums placed August 2, 1978 to April 1990).

- *218-W-4C, Trench 29 - 2,544 drums (drums placed September 8, 1983 to February 18, 1988).

- *218-W-4C, Trench 20 - 613 drums (drums placed October 3, 1980 to March 7, 1985).

- 218-W-4C, Trench $07-67$ drums (drums placed November 17, 1980 to March 3, 1987).

*These trenches also contain drums that are not covered with soil and are stacked or placed at the western end of the trench. These uncovered drums will have to be removed prior to any drum retrieval at these locations. The approximate number of uncovered drums at these trenches is given below:

\begin{tabular}{|c|l|c|}
\hline Trench 01 & Uncovered and stacked (Module 14) & 233 drums \\
\hline Trench 01 & Stacked and partially buried (Module 13) & 472 drums \\
\hline Trench 29 & Uncovered and stacked (no Module number) & 86 drums \\
\hline Trench 29 & Uncovered and stacked (Module 7) & 430 drums \\
\hline Trench 29 & Stacked and partially buried (Module 6) & 430 drums \\
\hline Trench 20 & Uncovered and stacked (Module 5) & 49 drums \\
\hline Trench 20 & Stacked and partially buried (Module 4) & 288 drums \\
\hline
\end{tabular}

The uncovered and stacked drum numbers given above for Trenches 01 and 29 reflect the drums removed during the FY 1996 and FY 1997 TRU drum relocation activities.

Trench 07 in 218-W-4B burial ground contains 8,080 drums, but the drums were placed in storage between August 13, 1973 and September 27, 1978, so most will not meet the vented drum requirement.

The number and type of boxes stored in the above listed trenches shown on the SWITS database are given as follows: 
Trench $04-38$ boxes: 37 metal and 1 FRP

Trench 01 - 70 boxes: 63 metal and 7 FRP

Trench $29-10$ boxes, all metal

Trench 20 - 78 boxes, all metal

Trench 07 - 73 boxes: 62 FRP, 10 metal, and 1 concrete*.

*this box weighs $83,000 \mathrm{lbs}$ and is the heaviest TRU waste container stored.

The SWITS database designates boxes in the following manner:

$\mathrm{CA}=$ FRP boxes

$\mathrm{CB}=$ concrete boxes

$\mathrm{CM}=$ metal boxes

Project W-113 documentation (written in 1994) and the present-day SWITS database disagree on the number of boxes in trenches 01 and 20. The Project W-113 documentation shows Trench 01 with 124 boxes and Trench 20 with 29 boxes. It should be noted that container movements have taken place within the past few years but recent photographs differ little from those taken years ago of the number of boxes visible on the western end of the trenches. From the presented data, trenches 04 and 29 appear to be the preferred retrieval trenches.

All TRU trenches in 218-W-4C have had drum and box placement mapping conducted as part of the 1994 Pilot TRU Retrieval Project or Project W-113. The drum mapping conducted for Trench 01 indicates that 12 drums containing high ${ }^{238} \mathrm{Pu}$ levels are stored in Module 4, tier four. The drums are disbursed throughout the tier. These ${ }^{238} \mathrm{Pu}$ drums were shipped to Hanford from the Savannah River Plant for criticality testing. The material was considered plutonium oxide scrap. The plutonium oxide is triple contained, in two aluminum cans and a stainless steel pipe, and positioned in the drum using a centering device. Each drum contains from 235 to 590 grams of approximately 85 weight percent oxide. Plutonium-239 fissile gram equivalent estimates, corrected to the year 2000, range from 153 to 373 grams. This waste form must be evaluated, in the future, for inclusion in the Master SAR and the ISB. This waste form will not be retrieved during the 10,000 drum retrieval project. Retrieval may be conducted from Trench 01 up to Module four.

Therefore, retrieval of the high-content ${ }^{238} \mathrm{Pu}$ drums from Trench 01 will occur in the next phase of TRU retrieval (after the 10,000 drum retrieval is complete) and efforts should be made to develop and bound accident scenarios so complete retrieval of Trench 01 drums can be conducted.

No classified waste drums or containers are stored in any of the $218-\mathrm{W}-4 \mathrm{C}$ trenches under consideration for TRU retrieval. Both the old R-SWIMS database and the current SWITS database indicated the majority of classified waste containers were placed in the $218-\mathrm{W}-3 \mathrm{~A}$ burial ground with other locations being: 218-W-3AE and 218-W-4B, Trench 07 and Trench V7. Trench 07 contains 45 drums of classified waste from Rocky Flats and Trench V-7 contains 21 drums also from Rocky Flats. Therefore, these two storage configurations (both within the same trench) are removed for consideration as a TRU drum retrieval site because they contain classified wastes and unvented drums. 
Vented drums were retrieved from Trenches 01 and 04 during the 1994 Pilot TRU Retrieval Project. Several hundred other drums were inspected during the course of the project using a borescope. Ten drums were retrieved from Trench 01 and 13 drums were retrieved from Trench 04. The drums retrieved from Trench 01 were placed in the trench in 1978 and the drums retrieved from Trench 04 were placed in 1980. All the drums inspected and retrieved were in good condition, although one drum from Trench 04 had a pin-hole. (The area immediate adjacent to the hole, about $1 / 2$ inch from the pin-hole, was sound metal reading 0.040 mils.)

Utilizing the presented data concerning the five trenches from $218-\mathrm{W}-4 \mathrm{C}$, Trench 04 meets all the selection criteria and is recommended to be the first site selected for TRU drum retrieval. The large number of drums and relatively small number of boxes, will support the waste retrieval process flow given in Section 5.3. Stored drum characterization information, completed by the 1994 TRU Retrieval Project or Project W-113, is well documented and should be used by the 10,000 TRU Drum Retrieval Project. If unvented TRU drums are discovered in the earlier modules, retrieval can be terminated and moved to the second recommended retrieval site, Trench 29. Retrieval from both trenches should be sufficient to meet the 10,000 drum retrieval goal. Trench 01 would be the third site recommended, but should only be retrieved down through module five, as module four contains the high-content ${ }^{238} \mathrm{Pu}$ drums. Trench 20 would be the fourth site recommended for retrieval.

The uncovered and stacked drums at the west end of trenches 01,20 , and 29 will need to be relocated prior to TRU retrieval from any of these trenches. It is recommended that the mobile, field assay unit be procured, set up, and tested for operation prior to relocating the drums. It is also recommended that the drum retrieval vehicle be procured and tested prior to relocating drums.

Conducting drum relocation prior to commencement of the 10,000 drum retrieval will (1) provide an opportunity to train staff; (2) test the actual equipment that will be used for drum retrieval; (3) use and evaluate operating procedures and forms; (4) use site support facilities and equipment; and (5) demonstrate the concept of open-air retrieval.

The drum relocation activities from Trenches 01 and 29, conducted in FY 1996 and FY 1997, determined that 79 percent of the drums relocated assayed as LLW. During future drum relocations, drums should be assayed in the trench by the mobile assay unit. Drums that assay as LLW should be placed in the LLW trench suggested in Section 5.3. Drums that assay TRU should be moved to the CWC for storage.

\subsection{RETRIEVAL METHODS}

The two methods for conducting TRU drum retrieval are (1) in a covered facility or dome; or (2) in open air. Advantages and disadvantages exist with each option selected. The retrieval method selected must be bounded by the funding allotted but the method selected must demonstrate that it meets employee, site, and off-site conditions of safe operation. The Hanford TRU Drum Retrieval Project is funded with $\$ 5$ million to conduct all preparatory work during FY 1999 and FY 2000. 


\subsubsection{Drum Retrieval Using a Trench Cover Structure}

In approaching this method of TRU drum retrieval, development of Project W-113 is the only data point at Hanford. The cost data shows the project costs to be extremely high and not able to be supported under current funding allotted to the TRU drum retrieval project. There are also several retrieval specific points that were not covered in the project. To use Project W-113 developmental data would require a complete evaluation of the project. A reevaluation of Project W-1 13 for the 10,000 TRU retrieval would produce little useable data and therefore, would not be beneficial to the development of the 10,000 drum retrieval project. Section 4.4 lists the items generated during development of Project W-113 that will be used in the 10,000 TRU drum retrieval project. A better approach is to evaluate the most current TRU retrieval projects being conducted at SRS and LANL and apply the information gathered to Hanford retrieval.

Both LANL and SRS successfully defended removal of dome structures over the TRU drum retrieval sites. The dome structures only provided a weather covering and both sites will conduct all future retrieve in open air. LANL will retrieve the 11,540 unvented drums and 51 FRP boxes from Pads \#2 and \#4 in open air starting in October 1998. SRS completed open-air retrieval of Pad \#5 containing 2,357 unvented drums on September 9, 1998. Both LANL and SRS were displeased with dome structure retrieval due to the reasons listed below:

1. The costs of the dome structures selected by both DOE sites were approximately $\$ 500,000$, excluding filtration and air handling systems.

2. Site preparation and installation costs were in addition to the dome structure costs.

3. Each dome would have to be moved during the course of retrieval at approximately $\$ 200,000$ per move.

4. The dome structures made it difficult to remove the soil overburden from the stacked drums. LANL reports that the dome made soil removal a safety hazard due to limited space for the soil removal equipment to operate and an industrial hazard from the standpoint of vehicle exhaust accumulation in the dome. As a result, work tasks were limited until the exhaust fumes could be removed by the air-handling system.

5. LANL attributed lingering dust conditions at retrieval to the dome structure. LANL indicated that full-face masks were worn to protect workers from dust. LANL expects no such dust problem in open-air retrieval and SRS has experienced no dust problems at openair retrieval.

6. The dome structure actually slowed work. The full-face masks worn for dust protection made work difficult and slowed retrieval progress.

7. SRS never used the HEPA filtration system or the retrieval face containment system purchased with the dome structures. This added additional cost for unneeded systems.

8. Dome site preparation, movement, and installation removed the project control from the project and placed it in the hands of others doing this work. Schedules may slip drastically as a result. 
Based on the results of TRU drum retrieval conducted under dome structures, it appears the dome structures provided little to the retrieval projects beyond a weather cover. SRS removed or never placed several items purchased with the retrieval domes and conducted retrieval from the first two pads with dome roll-up doors open.

It is worth noting that during open-air retrieval of the last pad at SRS (Pad \#5) the SRS site has received near record rainfall from hurricane driven rains. Retrieval site drainage was the main problem and gravel was hauled in to promote drainage. Even with this increased rainfall, SRS did not see significant work stoppages and completed retrieval of the TRU pad well ahead of schedule.

\subsubsection{Open-Air Retrieval of TRU Drums}

Open-air retrieval at Hanford would have many of the same weather obstacles as SRS or LANL. The soil conditions of Hanford and LANL are similar being dry and dusty. SRS has a greater annual rainfall total than Hanford or LANL. Both LANL and Hanford have about the same winter temperatures and snowfall and both must deal with high winds. LANL has additional summer concerns with heavy rains occurring May through July.

The assessment of TRU drum retrieval conducted by SRS and LANL has lead to open-air retrieval. Each site took a different approach to achieve open-air retrieval but both sites came to the same conclusion. The conclusion was based at SRS on testing equipment to meet safety design criteria and retrieval was a sum of existing burial ground operations. The conclusion at LANL was based on operator experience, training, and the fact that no contamination or incidental releases occurred during retrieval of the first TRU pad.

During the 1994 TRU Pilot Retrieval Project, no problems were generated from open-air TRU drum retrieval at the two sites. The retrieval was conducted from July to November with no incident of radionuclide contamination. Operations were occasionally hampered by winds in excess of $15 \mathrm{mph}$, early morning frost, or occasional rainfall.

Hanford should proceed with open-air retrieval as the preferred method to retrieve TRU drums from 20-year retrievable storage. All data generated at SRS or LANL have shown that open-air retrieval is the most cost-effective and viable option for the retrieval of TRU drums. Hanford should use past experience and data gathered from the 1994 Pilot TRU Retrieval, the 1996 and 1997 TRU drum relocation activity, and SRS and LANL data to bound the open-air TRU retrieval within existing Solid Waste documentation and operations.

Hanford 10,000 TRU drum retrieval project should use the following data and information for establishing the open-air retrieval method:

1. The supportive gas and soil sampling results taken during 1994 Pilot TRU Retrieval.

2. The radiological air monitoring results taken during 1994 Pilot Retrieval.

3. The drum corrosion data gathered during 1994 Pilot Retrieval 
4. The capability of solid waste to relocate TRU drums stacked on the asphalt trenches without soil cover.

5. The experience with heavy equipment to move, set, and ship TRU drums.

6. The experience of moving 1,200 TRU drum from TRUSAF to CWC.

6. Previously retrieved TRU drum shipments.

8. The supportive corrosion data, gas sampling data, lack of airborne contamination, and sampling data from the Morton study.

9. Good records for drum identification and location within modules.

10. The documentation produced by LANL and SRS for support of open-air retrieval.

11. The experience of LANL and SRS management in project development.

12. Air and soil sampling results from SRS and LANL.

13. Corrosion data from SRS and LANL.

14. Retrieval and assay crew sizing from SRS and LANL.

15. Mobile assay equipment requirements from $\mathrm{LANL}$ and project $\mathrm{W}-113$.

The Hanford TRU Drum Retrieval Project may wish to establish a project base from this planning document. The planning base will evaluate all functions related to TRU drum retrieval and assign a weighed scale or priority to rate each function. This will aid in defining the required tasks, establishing task priorities, setting the sequence on which the tasks should be completed, defining the conflicts in completing simultaneous tasks, and providing more detail beyond that listed in Sections 6.2 and 7.2.

\subsection{CH-TRU DRUM RETRIEVAL PROCESS FLOW}

Conducting CH-TRU drum retrieval, performing assay, overpacking (as required), disposing of wastes that assay LLW, and shipping TRU wastes to CWC in the same trench will be very difficult from an operational and safety standpoint. As an example, Trench 04 is recommended in Section 5.1 as the first trench to retrieve. The first two most westerly modules in Trench 04 , Modules 19 and 18, contain 640 drums whose records show that the drums individually contain less than 0.01 gram of plutonium and read less than $1 \mathrm{mR}$ at contact. These drums will probably assay as LLW. If these drums assay as LLW and are stacked in the trench, they will require an area equal to 27 rows of drums, six drums deep, stacked four drums high. This area would be greater than one module. This would cut the operating trench space from 26 feet wide to 13 feet wide for the first 54 feet of the trench. Therefore, drum assay, drum overpacking, LLW staging for disposal, and TRU drum staging for shipment must take place in the other 13 feet of the trench. If this were to occur, there would be no room for drum retrieval. 
The space utilization would worsen when Module 16 was retrieved. Module 16 contains several boxes, that will not be retrieved, and must be stacked in the trench. Useable trench space to safely and efficiently conduct retrieval operations would continually diminish. Drums would also have to be moved several times, thereby increasing accident potential. The trench would also have to provide space for the mobile assay unit (an 8-foot by 40-foot trailer), drum feed and discharge from the assay unit, an overpacking area, an area to survey and label drums, a shipping area, and working space for retrieval and shipping vehicles.

The 10,000 CH-TRU drum retrieval needs to be developed as an efficient and safe operation. Assay, overpacking, LLW disposal, and TRU drum shipping to CWC need to be conducted at a location other than the retrieval trench. A well defined process flow with open working spaces is required.

The pre-start drum retrieval activities will determine the condition of the modules to be retrieved and prepare the site for retrieval. These activities will include the following:

1. Placing support facilities near the site for equipment storage and employee needs. These may include a temporary trailer for office space, change rooms, storage of supplies, etc. A new temporary facility would only require electrical power drops for hook-up as no water will be supplied. (Adjacent trailers presently underused by another company or division need to be evaluated to fulfill these needs.)

2. Placing additional continuous air monitors near the retrieval site as instructed by the Environmental Monitoring organization.

3. Conducting gas sampling through the riser pipes at the selected retrieval sites. This sampling should be conducted by the Industrial Hygiene organization and sampled for combustible gases and the percent oxygen. The sampling should include borescope inspection of the risers to determine which risers are viable.

4. Radiological employees will support the gas sampling effort so some degree of contamination sampling in the riser pipes will be conducted.

5. Appropriate fencing, roped-off areas, and signs will be used to identify the retrieval site, specify work areas, provide entry requirements and limitations, identify emergency routes and information, and identify points of contact and other needed field information.

6. A pre-retrieval probe will be conducted to locate the top of the drum stack. These probe stakes may be color coded to identify depth of soil cover over the drum stacks. The stakes will be left in place as an aid to uncovering drum modules. No GPR is planned for any drum retrieval site.

7. Trenches totally covered with soil will have the westerly coordinate for the last module of the trench surveyed and marked.

8. The drum mobile assay unit will be set up in a trench. Trench 24 is the recommended trench for the $218-\mathrm{W}-4 \mathrm{C}$ burial ground. No services will be required for the assay unit; it 
will be self-contained. The mobile assay unit will be mounted in a trailer and set up to provide efficient drum flow to and from the unit.

9. Drum inspection areas (including radiological survey, drum integrity, and labeling), drum overpacking, staging areas for TRU drums to be shipped, and staging areas for LLW prior to stacking will be identified and marked.

After completing the pre-retrieval activities, the retrieval operations will proceed in the general manner as next described.

\section{Retrieval:}

1. The trench approach ramp soil is removed by front-end loader or a Skytrak type retrieval vehicle with the front-end loader attachment. The soil will be moved adjacent to Trench 24 or as needed in the burial ground. An efficient way to haul the removed soil will be with a dump truck. The route to Trench 24 can be along the east shoulder of Dayton Avenue or the back dirt road south of Trench 07 .

2. Soil removal continues until the west face of the module is exposed. Survey markers are used as aids.

3. Soil cover on top of the most westerly module is removed using a Skytrak-type retrieval vehicle with the front-end loader attachment. The retrieval vehicle can work from the north or south rim of the trench or from the asphalt ramp area. (The Skytrak vehicle has a reach of 30 feet.) The color-coded overburden stakes are used as a guide to identify the module top. (The module top is covered with $3 / 4$-inch sheets of plywood.) Any contaminated soil found during Steps 1 through 3 will be placed in drums or boxes as deemed appropriate by the radiation monitor.

4. Module overburden soil is removed from one module at a time. (As TRU drum retrieval progresses and experience increases, this may change.)

5. The correct trench wall slope $(1 \mathrm{~V}$ to $1.5 \mathrm{H})$ is maintained by the retrieval vehicle. A frontend loader attachment that has tilt capability should be procured.

6. Soil adjacent to the trench (north and south) will be removed by backhoe or the retrieval vehicle.

7. An industrial hygienist and radiation monitor will sample and assess retrieval site conditions. They will provide the "safe to proceed" indication.

8. An inner drum module inspection can also be performed using the 30 -foot borescope with video and still camera options. Using the borescope, an inspection of general drum condition can be made several rows deep into the module prior to retrieval.

9. Once soil is removed from the module and the safe slope established, personnel will roll the tarp back to expose the trench drum face (west end). 
10. Using the Skytrak-type vehicle basket attachment, which needs to hold two people, plywood may be removed from the top of the module to aid in Steps 7, 8, and 9.

11. Plywood removed from the modules is to be stacked, then removed to Trench 24, where it will be reused while stacking LLW drum tiers.

12. The radiation monitor and drum retrieval lead will be raised up in the Skytrak basket to visually inspect accessible surfaces of the drums and survey the condition of the top tier of drums in the modules (Row L, drum positions 1 through 12) most westerly row. Drum location sheets and SWITS data sheets for each drum will be available and used to identify and provide information concerning the retrieved drums.

13. A retrieved drum data form will be generated for each drum retrieved. The form will record original drum data from the SWITS database and new data about the retrieved drums, such as drum number, weight, size, surface dose rate, retrieval date, drum condition, and other pertinent data as required.

14. The drum will be retrieved using the Skytrak-type vehicle drum grabber attachment and moved to the designated drum laydown area. During retrieval, drums may first need to be raised slightly to inspect the drum bottom or turned to inspect the rear face.

15. If the drum is damaged or shows suspect drum integrity, the PPE will be adjusted as directed, and the damaged area will be wrapped with plastic sheeting or secured for contamination control. Pick drum slowly and inspect the bottom. Move the drum to an 85 gallon overpack positioned as close as possible to the damaged drum and lower the drum into the overpack.

16. When boxes are encountered in the module, they will be inspected in the same manner but removed by the retrieval vehicle, using fork attachments or other equipment, and placed in the designated lay-down area at the trench perimeter.

17. If a high dose rate drum is encountered, lead shielding will be attached to the drum and the drum placed in an overpack. The shielding required will be noted on the retrieved drum data form. Both pre- and post-shielded dose rate will be recorded on the form. The drums requiring shielding may be segregated at the assay laydown area and assessed for batch assay.

18. If contaminated soil is encountered during retrieval, the PPE will be adjusted as directed, and the soil will be removed with tools and placed in drums. The filled drums will be accumulated in the retrieval trench for later movement to Trench 24 and assay.

19. Incidental drums without vent clips may be overpacked in vented 85 -gallon drums.

20. At the retrieval laydown area, the drum will be completely surveyed, weighed, labeled as required, and the retrieved drum data sheet completed.

21. The drum will then be moved to the staging area for later movement to the assay area in Trench 24. 
HNF-3580, Rev. 0

22. As retrieval progresses, the tarp will be rolled back and plywood sheets removed and stacked. At day's end, the tarp will be draped over the retrieval face and secured.

23. The drum retrieval will continue in this manner tier by tier until the retrieval from the module is complete. The drum retrieval process will then start over on the next module by following Steps 3 through 22 .

The concern of a contamination spread while moving drums from one trench to another is extremely low. Hanford 1994 Pilot TRU retrieval demonstrated that no airborne contamination was detected at retrieval sites and this has been supported by SRS and LANL TRU drum retrieval projects. SRS reports only 16 of 6,000 retrieved drums required overpacking due to questionable drum condition while LANL reported 138 of 5,000 retrieved drums required overpacking. It should be noted that original project design criteria at LANL estimated overpacking would be required for 50 percent of the retrieved drums while SRS planned to overpack 100 percent of retrieved drums. Contamination spread will also be controlled by complete drum surveys prior to drums being moved from the retrieval trench. The survey/assay operations will proceed in the general manner as next described.

Assay:

1. Prior to movement of the drums to the assay laydown area, all drums will be inspected to assure the retrieved drum data form is complete for each drum, drums are correctly labeled, and movement paperwork is correct.

2. Drums will be transported from the retrieval trench to Trench 24 using a Skytrak-type vehicle or a transport truck. The route of movement can be along the east shoulder of Dayton Avenue or the back dirt road south of Trench 07. Drums will be moved to maintain minimum drum backlog requirements at assay.

3. The retrieved drums will be placed in the assay laydown area in Trench 24. The assay laydown area may be segregated into 55-gallon, 85-gallon, 85-gallon drums with shielding, etc. to expedite assay of certain drum types.

4. Drums to be assayed will be moved to the mobile assay unit drum in-feed area.

5. The drums will be assayed and moved out of the unit for pick-up. The assay will be a LLW-TRU partition assay. Drums will keep the original assay value shown as they were placed in retrievable storage.

6. After assay, the drums that assay TRU will be segregated for shipment to CWC and drums that assay LLW will be moved to the rear (east end) of the trench for stacking. TRU drums shipped to CWC will maintain the original placement assay value.

7. LLW drums will be stacked in the same manner as drums exiting retrieval, in rows 12 drums wide and four drums high. The plywood removed from the retrieval trench will be placed between and atop the LLW drum tiers. 
HNF-3580, Rev. 0

8. TRU drums may be overpacked to meet acceptance criteria of the CWC facility. If this is to be done, the drums will be lowered in the overpack, the lid ring bolt torqued to specifications, the drum labeled, and the retrieved drum data sheet changed to reflect a 55-gallon inside an 85-gallon overpack.

9. Final drum inspections, labeling, and surveys will be conducted on the TRU drums, shipping paperwork prepared, and the drums staged for shipment to CWC.

10. The drums will be shipped to $\mathrm{CWC}$ as required to keep Trench 24 in an effective operational mode.

11. SWITS database information will be adjusted to reflect drum movement locations, drum size changes from 55-gallon to 85-gallon, (if drums are overpacked), drum content changes (if lead shielding is added), dose changes, any drum number changes, etc.

\subsection{HANFORD CH-TRU DRUM RETRIEVAL NEEDS}

\subsection{EQUIPMENT AND FACILITY}

A retrieval vehicle will be required to retrieve stacked drums from the retrieval trench, unstack and move boxes, move other buried waste containers (i.e., double drums), and move retrieved drums and overpacked drums to the assay trench. One versatile vehicle is preferred to perform the several required functions of retrieval. The retrieval equipment to be procured must be able to meet the following requirements:

1. The vehicle shall be able to remove drums from a close-stacked array with a minimum capability of a 20 foot vertical reach and 10 foot horizontal reach, when extended to the 20 foot vertical. The drum grabbing feature needs to be able to open and close around a 55-gallon drum and an 85-gallon drum and hold them securely for completion of $\# 2$.

2. Using the grabber attachment, the vehicle shall be able to lift and transport retrieved drums weighing up to $1,000 \mathrm{lbs}$ when extended to values given in Item 1 .

3. The vehicle shall be able to accept a front-end safety basket attachment that will hold two people and equipment weighing up to $800 \mathrm{lbs}$. The minimum reach requirement as stated in Item 1 applies.

4. The vehicle shall be able to accept forklift attachments (two forks) that can be adjusted side-to-side to a spacing of 60 inches and have a minimum length of 60 inches. The vehicle with the fork attachments shall be able to lift a load weighing $15,000 \mathrm{lbs}$ from 10 feet off the ground. Additional weights may be added to the vehicle to accomplish this.

5. The vehicle front-end loader attachment shall have $X-Y$ tilt capability to 45 degrees. The loader bucked should have a minimum capacity of one yard. 
6. The vehicle shall be able to operate over sandy and loose soil, with appropriate tires, for transporting, loading, and moving both 55-gallon and 85-gallon drums.

7. A recommendation that the vehicle have a backhoe attachment on the back that may be removable.

8. The vehicle should have comfortable seating for a single operator with gears to control vehicle speed from one to $20+\mathrm{mph}$. The vehicle shall have a protected cab.

Also needed for TRU drum retrieval will be a mobile segmented gamma scan passive-active neutron assay system. The system should meet the following requirements:

1. Trailer-mounted on a standard 40-foot trailer, not exceeding the width of a standard trailer.

2. The system should be self-contained with a means of suppling power as needed to operate all system components.

3. The system may have drum feed and discharge rollers or tracks that extend beyond the footprint of the unit given above.

4. The unit shall be able to perform TRU drum assay for 55-gallon and 85-gallon drums.

5. The unit will include SGS and PAN assay capabilities to discriminate LLW from TRU wastes at $100 \mathrm{nCi} / \mathrm{g}$.

6. The unit should be able to assay drums weighing up to $1,200 \mathrm{lbs}$.

7. Be able to assay several waste forms to the specifications given in Item 5 , including lead shielding, several containers within a drum, drum within a drum, and a waste forms from plastic and paper to metals and concrete.

8. The unit will provide an assay results printout of each drum after assay.

9. The unit shall be controlled and conditioned, utilizing its own power supply capabilities, so as to maintain system operation when outside temperatures are between $10^{\circ} \mathrm{F}$ and $110^{\circ} \mathrm{F}$.

10. Be able to be set up and leveled on up to a 20-degree slope.

No other large equipment will be required for the project. The use of large equipment from the 200 Area heavy equipment operations may need to be used. This would include (1) a large frontend loader needed to uncover the approach ramps of covered trenches; (2) a dump truck to haul the removed ramp soil to the Trench 24 area (or as needed in the burial ground); and (3) a truck with side walls to transport retrieved TRU drums to $\mathrm{CWC}$.

Other small equipment needed for TRU drum retrieval will include (1) drum lifting gig to allow lowering a drum into an 85-gallon overpack; (2) installation of at least two continuous alpha air monitors for air sampling during drum relocation and retrieval operations; and (3) industrial hygiene monitoring equipment or supplies. 
HNF-3580, Rev. 0

The only facility needed to support the TRU Drum Retrieval Project will be temporary trailer space to provide storage of small equipment and supplies, to act as an office area, to provide a change room, to provide employee cool-down and warm-up, and to provide a meeting room. The trailer need not have running water for a kitchen or restroom. Bottled water will be provided and two portable toilets could be provided for the employees. A temporary trailer could be moved to the site or underused trailers, near the retrieval sites, could be secured. Additional storage needs may be supplied by Conex storage boxes.

\subsection{TRU DRUM RETRIEVAL TASKS}

Several tasks must be identified during the planning for TRU drum retrieval, prioritized, and completed to the schedule. The identified tasks of the TRU drum retrieval project are identified below. This list is not all-inclusive, but rather the compilation of tasks known presently. During project-specific baseline planning, other tasks may arise or some of these tasks may be changed or deleted. The tasks will not be listed in any specific order but will be listed for completion by fiscal year. The task completion list assumes that project funding, as now constituted, will not be altered. There may be several sub-tasks that are not listed under each task at this time. The further breakdown of each individual task element may be conducted during the project baseline, functions, and task prioritization.

\section{Tasks for completion in FY 1999}

1. Prepare a TRU Program Management Plan detailing tasks, responsibilities, schedules, and estimated costs.

2. Assign a dedicated TRU retrieval project lead and staff.

3. Perform a project baseline functions and priority analysis to define all aspects of retrieval, set need, and priority. The task will support the project approach of this planning document or provide recommendations to alter the approach.

4. Develop the strategy for Washington State Department of Ecology (Ecology) and DOE presentation that will establish an agreement with the agencies that drums removed from the trench of retrieval for assay, overpacking, or stacking are not newly generated waste. The drums are disposed now and movement to a different trench does not constitute generation of newly generated waste. TRU drums moved to CWC will be managed as newly generated waste.

5. Prepare an addendum to the Criticality Safety Evaluation 91-003 to rebaseline the 36 remaining high fissile drum density sequences from an as-shipped to as-stacked basis. The addendum should extend the drum storage life on asphalt pads (or similar storage) commensurate with corrosion finding of the 1994 Pilot TRU Retrieval Project.

6. Complete drum stacking records for module locations of unknown drums. The goal is to confine the bound drum locations within a specific drum shipment. 
HNF-3580, Rev. 0

7. Update the Master SAR to bound the TRU drum retrieval project drums selected for retrieval according to this document or subsequent data gathered in Items 1 and 3.

8. Update the Interim Safety Basis to bound the TRU drum retrieval project drums selected for retrieval according to this document or subsequent data gathered in Items 1 and 3.

9. Provide the WAC to bound the TRU drums retrieved during this project for entrance into the CWC.

10. Provide the procurement specification for the mobile assay system.

11. Develop a sampling and monitoring plan for air and soil sampling.

12. Locate a trailer suitable to support the needs of the project.

13. Evaluate SARP and transportation requirements for the retrieved 55-gallon drums and any required changes to the existing 85 -gallon drum overpack.

14. Evaluate the requirements to any Performance Assessment or Burial Ground Closure elements.

15. Evaluate the need for NEPA documentation to bound TRU drum retrieval.

16. Evaluate DOE Orders or regulations that may influence or bound TRU drum retrieval.

17. Evaluate SRS and LANL open-air retrieval success in meeting their established milestones specific to downtime attributed to open-air retrieval.

18. Begin procurement of the mobile assay system.

19. Write the specification for the drum retrieval vehicle.

20. Write the Sampling Analysis Plan.

\section{Tasks for completion in FY 2000}

1. Finish procurement of the mobile assay system.

2. Procure the drum retrieval vehicle.

3. Procure project small equipment and personnel resources.

4. Finalize requirements for the project support trailer(s). Hook up utilities, if required.

5. Write procedures for drum relocation and TRU drum retrieval.

6. Write the training requirements for TRU drum retrieval and conduct training. 
7. Prepare TRU drum retrieval data sheets consistent with SWITS needs.

8. Prepare the mobile assay testing documentation.

9. Conduct TRU drum relocation from Trenches 01,20 , and 29 to establish a TRU drum retrieval basis.

10. Establish TRU drum retrieval project review methodology.

11. Conduct gas sampling of retrieval trench riser pipes.

12. Procure 85-gallon overpack drums as needed.

13. Provide field signs, requirements, and isolation of the drum relocation activity.

14. Survey west coordinates of soil covered trenches, stake, and label to identify.

15. Set up and outline drum segregation areas in the assay trench. Outline separate areas required for assay, assay feed and discharge, shipping, staging for assay, staging for stacking, overpacking, etc. Consider process flow needs and parameters. Several of these areas will be repeated in the retrieval trenches.

16. Conduct an evaluation of TRU drum relocation and the use of TRU drum retrieval parameters. Alter needed methods as they may need to be applied to TRU drum retrieval. Change procedures and operational parameters to reflect the evaluation findings.

17. Set up and test mobile assay equipment in Trench 24 or selected trench.

18. Conduct a management evaluation of TRU drum relocation findings and prepare letters to WMH and DOE upper management supporting the findings and alteration to be made for conducting TRU drum retrieval.

19. Establish NDE (borescope) requirements for use in gathering information in modules prior to the start of retrieval.

20. Conduct TRU drum retrieval review for startup.

\subsection{SCHEDULE, COSTS, AND MANPOWER LOADING}

\subsection{SCHEDULE}

The schedule of completion of tasks will be broken down by fiscal year quarter. The ROM costs are given in Section 7.3. If costs extend over several quarters, the total cost will be shown in the first quarter and carryover will be noted in the subsequent quarters. The task numbers listed in Section 6.2 will be carried forward in this section. 
HNF-3580, Rev. 0

\section{First Quarter FY 1999 tasks:}

\#1 - Prepare TRU Program Management Plan

\#2 - Assign dedicated TRU retrieval project lead and staff.

\#3 - Conduct project baseline functions and priority analysis

\#6 - Complete drum stacking records for unknown drum positions

\#8 - Update ISB to bound TRU drum retrieval (first half of costs )

\#4 - Develop strategy for Ecology and DOE presentations - waste not newly generated

\#20 - Write Sampling Analysis Plan

\#13 - Evaluate SARP requirements (first half of costs)

\section{Second quarter FY 1999 tasks:}
\#13 - SARP requirements (finish)
\#8 - Update ISB - (finish)
\#7 - Update Master SAR to bound TRU drum retrieval
\#5 - Prepare addendum to the CSER
\#9 - Provide Waste Acceptance Criteria to CWC
$\# 10$ - Complete procurement specification for mobile assay system
$\# 15$ - Evaluate NEPA documentation (first half of costs)

\section{Third quarter FY 1999 tasks:}

\#18 - Start procurement of the mobile assay system (first quarter of costs)

\#16 - Evaluate required DOE Orders and regulations

\#14 - PA and Closure requirements constancy

\#15 - NEPA documentation (finish)

$\# 11$ - Develop sampling and monitoring plan

\#17 - Evaluate SRS and LANL open-air retrieval success (first half of costs)

\section{Fourth quarter FY 1999 tasks:}

\#17 - Evaluate SRS and LANL open-air retrieval success (finish)

$\# 19$ - Write the procurement specification for the drum retrieval vehicle.

\#12 - Locate retrieval support trailer

\#18 - Procurement of mobile assay system (second quarter of costs)

First quarter FY 2000 tasks:

\#1 - Procure mobile assay system (third quarter of costs, carryover from FY 1999)

\#2 - Procure the drum retrieval vehicle

\#5 - Write draft procedures for drum relocation and retrieval

\#7 - Prepare drum relocation and retrieval data sheets to SWITS requirements

\#6 - Write training requirements 
Second quarter FY 2000 tasks:

\#1 - Procurement of mobile assay system (finish)

\#3 - Procure small equipment and personnel resources

\#10 - Establish TRU drum review methodology (first half of costs)

\#12 - Procure 85-gallon overpack drums (first half of costs)

\#4 - Set trailer and hook-up utilities or secure underused trailer near site

\#19 - Establish NDE borescope requirements

\#13 - Provide field signs for drum relocation

\#8 - Prepare mobile assay testing documentation (first half of costs)

Third quarter FY 2000 tasks:

\#8 - Prepare the mobile assay testing documentation (finish)

\#12 - Procure 85-gallon overpack drums (finish)

$\# 10$ - Establish TRU drum retrieval methodology (finish)

\#17 - Set up and test mobile assay system in Trench 24

$\# 15$ - Set up drum segregation areas in trenches

\#16 - Conduct evaluation of TRU drum relocation (first half of costs)

\#9 - Conduct TRU drum relocation from Trenches 01,20 , and 29 (first half of costs)

Fourth quarter FY 2000 tasks:

\#9 - Conduct TRU drum relocation (finish)

\#11 - Conduct gas sampling of retrieval trench riser pipes

$\# 14$ - Survey west coordinate of soil covered retrieval trench and stake

$\# 16$ - Conduct evaluation of drum relocations (finish)

$\# 18$ - Conduct management evaluation of TRU drum relocation

\#20 - Conduct TRU drum retrieval review for startup

\section{$7.2 \operatorname{cosTS}$}

The funding allocated to the TRU drum retrieval project is $\$ 810,000$ for FY 1999 and $\$ 4.163$ million for FY 2000. The actual retrieval years are funded as follows:

- $\quad$ FY 2001 - \$4.5 million

- FY 2002 - \$4.571 million

- FY 2003 - $\$ 6.074$ million

- FY 2004 - \$6.2 million

The funding for FY 1999 does not support the acquisition of required capital equipment. The cost of the mobile assay system is approximately $\$ 1.2$ to $\$ 1.5$ million and has a lead time of about seven to nine months to receive after the procurement bid is placed. The funding for FY 1999 needs to be increased by approximately $\$ 750,000$ to begin procurement of the mobile assay system in FY 1999. The needed funding in FY 1999 can be taken from FY 2000 funding and decrease the FY 2000 funding to $\$ 3.353$ million. 
A cost comparison cannot be achieved in this document using SRS and LANL cost data. Both SRS and LANL are involved in a cost assessment of their TRU retrieval projects being conducted by DOE-HQ. Individual task or element cost data will not be available from the two sites until DOE-HQ finishes the cost assessment for each site. The assessment is evaluating if the projects are providing DOE with fair and reasonable charges for conducting the TRU retrieval projects at the two sites.

Utilizing the TRU drum retrieval methodology presented in this document, few pieces of retrieval equipment will require procurement. Costs of major equipment and supplies are as follows:

1. Drum retrieval vehicle (Skytrak type) - $\$ 100,000$ to 150,000

2. Mobile drum assay system - $\$ 1.2$ to 1.5 million

3. 85-gallon galvanized, filtered overpack drum - $\$ 170 /$ ea or $\$ 850,000 /$ total*

*If all retrieved drums that assay as TRU waste (assume 50 percent of the 10,000 ), require overpacking prior to shipment to the CWC facility, the total cost will be $\$ 850,000$.

Individual cost figures will be given in Section 7.3 in the ROM for each task. The task numbering, as provided in Section 7.1, will continue into this section. Individual tasks will provide ROM costs required to complete the individual tasks. A finalized cost table and accompanying schedule will be presented after completion of Tasks 1 and 3 during FY 1999.

\subsection{ROUGH ORDER OF MAGNITUDE COSTS}

This section provides ROM costs to complete tasks. The task may be carried through several fiscal year quarters or between fiscal years. In that case, the total to complete the task will be listed by the first time the task entry appears. If the task costs are split between fiscal years, costs will be shown for each fiscal year. A final schedule, in the form of a timeline, will be included with the TRU Program Management Plan and project baseline functions and priority document.

It is anticipated project personnel will oversee or generate much of the project documentation. The following cost totals for FY 1999 and FY 2000 do not include FY quarterly break-out costs. Total costs are added to each FY, as noted, for:

1. Retrieval personnel: two operators, one HPT, and one equipment operator.

2. The TRU retrieval lead.

3. Management and secretarial support only for items 18 and 20 in the fourth quarter, FY 2000.

Combined costs for Items 1 and 2 would total about $\$ 280,000$ to $\$ 350,000$ in FY 1999 and approximately $\$ 420,000$ in FY 2000 . The drum relocation activity during the third and fourth quarters of FY2000 is included in this total. The cost totals also do not include assay operation personnel in the last two quarters of FY 2000 for two operators, one HPT, and one engineer. 
These costs are estimated to be approximately $\$ 175,000$. Some of these costs may be included as part of the mobile assay fabrication and testing contract. The training total will include assay operations training.

\section{First quarter FY 1999 tasks:}

\#1 - Prepare TRU Program Management Plan - $\$ 40,000$

\#2 - Assign dedicated TRU retrieval staff - $\$ 5,400$

$\# 3$ - $\quad$ Project baseline functions and priority analysis - $\$ 36,800$

\#6 - Complete drum stacking records $-\$ 12,800$

\#8 - Update ISB to bound TRU drum retrieval - $\$ 51,200$

\#4 - Ecology and DOE strategy - not newly generated - \$11,200

$\# 20$ - Write Sampling Analysis Plan - $\$ 16,000$

\#13 - Evaluate SARP requirements - $\$ 19,200$

\section{Second quarter FY 1999 tasks:}

\#13 - SARP requirements - Cost shown above

\#8 - Update ISB - Cost shown above

\#7 - Update Master Safety Analysis Report to bound TRU drum retrieval - $\$ 32,000$

$\# 5$ - $\quad$ Prepare addendum to the CSER - $\$ 22,400$

\#9 - Provide WAC to CWC - $\$ 57,600$

$\# 10$ - Procurement specification for mobile assay $-\$ 9,600$

$\# 15$ - Evaluate NEPA documentation - $\$ 17,600$

Third quarter FY 1999 tasks:

\#18 - Start procurement of the mobile assay system - $\$ 750,000$ for FY 1999

$\# 16$ - Evaluate required DOE Orders and regulations - $\$ 32,000$

$\# 14$ - PA and Closure requirements constancy - $\$ 4,800$

$\# 15$ - NEPA documentation - Cost shown above

$\# 11$ - Develop sampling and monitoring plan - $\$ 20,800$

$\# 17$ - SRS and LANL open-air retrieval success - $\$ 16,800$

\section{Fourth quarter FY 1999 tasks:}

$\# 17$ - SRS and LANL open-air retrieval success - $\$ 16,800$

$\# 19$ - Procure specification drum retrieval vehicle - $\$ 9,600$

$\# 12$ - Locate retrieval support trailer - $\$ 6,000$

\#18 - Procure mobile assay system - Cost shown for FY 1999

Total FY 1999 ROM Task Costs:

Total FY 1999 ROM Staff Costs:

Total FY 1999 Costs:
$\$ 438,600$

$+\$ 350,000(\text { high })^{*}$

$+\$ 280,000$ (low)*

$\$ 788,600$ (high) $^{*}$

$\$ 718,600$ (low)* 
HNF-3580, Rev. 0

FY 1999 Budget Uncommitted Funds:

Total FY 1999 Budget:

FY 1999 Unbudgeted Item (Mobile Assay):
$\$ 91,400$ to $\$ 21,400$

$\$ 810,000$

$\$ 750,000$

*Does not include managerial or secretarial support.

\section{First quarter FY 2000 tasks:}

$\# 1$ - Procure mobile assay system - $\$ 750,000$ for FY 00

$\# 2$ - Procure the drum retrieval vehicle - $\$ 150,000$

\#5 - Draft procedures - drum relocation/retrieval - $\$ 25,600$

\#7 - Drum relocation/retrieval data sheets to SWITS - $\$ 3,200$

\#6 - Write training program - $\$ 25,600$

\section{Second quarter FY 2000 tasks:}

\#1 - Procure mobile assay system - Cost shown above

\#6 - Write training program - Cost shown above

\#3 - Procure small equipment/personnel resources - $\$ 35,000$

$\# 10$ - Establish project review methodology - $\$ 20,800$

$\# 12$ - Procure 85-gallon overpack drums (commit funds) - $\$ 850,000$

$\# 4$ - $\quad$ Set trailer and hook-up utilities - $\$ 96,000$

$\# 19$ - Establish NDE borescope requirements - $\$ 6,400$

$\# 13$ - Provide field signs for drum relocation - $\$ 6,800$

$\# 8$ - Prepare mobile assay testing documentation - $\$ 9,600$

Third quarter FY 2000 tasks:

\#6 - Write training program - Cost shown above

\#8 - Mobile assay testing documentation - Cost shown above

$\# 10$ - Establish project review methodology - Cost shown above

$\# 17$ - Mobile assay set up and testing - $\$ 56,600$

$\# 15$ - Set up drum segregation areas in trenches - $\$ 9,600$

$\# 16$ - Conduct evaluation of TRU drum relocation and procedural alterations - $\$ 28,800$

\#9 - Conduct TRU drum relocation - Costed in staff

\section{Fourth quarter FY 2000 tasks:}

\#9 - Conduct TRU drum relocation - Costed in staff

$\# 11$ - Gas sampling of retrieval trench riser pipes - $\$ 9,600$

$\# 14$ - Survey and stake west end of retrieval trenches - $\$ 4,000$

$\# 16$ - Conduct evaluation of drum relocations and procedural alterations - $\$ 12,800$

$\# 18$ - Management evaluation of TRU drum relocation - $\$ 10,800$

$\# 20$ - Prepare and conduct TRU drum retrieval review - $\$ 280,000$

Total FY 2000 ROM Task Costs:

$\$ 606,200$ 
HNF-3580, Rev. 0

Staff Costs:

Retrieval

$\$ 420,000$

Assay (some costs may be included in mobile assay contract)

$\$ 175,000$

Equipment \& Materials Costs:

\section{Assay \\ Retrieval Vehicle \\ Overpack Drums $(5,000)$ \\ Small Equipment \& Supplies}

Total FY 2000 ROM Costs:

Total FY 2000 Budget:

(After movement of $\$ 750,000$ to FY 1999)
$\$ 750,000$

$\$ 150,000$

$\$ 850,000$

$\$ 35,000$

$\$ 2,986,200^{*}$

$\$ 3,353,000$

*Does not include management and secretarial support, except for Items 18 and 20.

\subsection{REFERENCES}

Anderson, B. C., 1989a, Stored, Contact-Handled Transuranic Waste Characterization at the Hanford Site, WHC-EP-0223, Westinghouse Hanford Company, Richland, Washington.

Anderson, B. C., D. R. Duncan, 1989b, Sampling Plan for Retrievably Stored Contact-Handled Transuranic Waste at the Hanford Site, WHC-EP-0226, Westinghouse Hanford Company, Richland, Washington.

Anderson, B. C., et al., 1990, Contact-Handled Transuranic Waste Characterization Based on Existing Records, WHC-EP-0225, Westinghouse Hanford Company, Richland, Washington.

Demiter, J. A., 1988, Glovebox Site Evaluation Study for Characterization of Retrievably Stored Solid TRU Wastes, WHC-IP-0292, Westinghouse Hanford Company, Richland, Washington.

Demiter, J. A., 1993, Explosion Testing for the Container Venting System, WHC-EP-0686, Westinghouse Hanford Company, Richland, Washington.

Demiter, J. A., D. R. Duncan, D. C. DeRosa, 1994, Results of 1994 Pilot TRU Retrieval, Unpublished Draft.

Demiter, J. A., 1997, Transuranic Drum Retrieval and Vent/Purging At The Savannah River Site - Trip Report, SESC-97-259 Letter Report, SGN Eurisys Services Corporation, Richland, Washington.

Demiter, J. A., 1998, Transuranic Retrieval and Vent/purging at the Los Alamos National Laboratory - Trip Report, COGEMA-98-879 Letter Report, COGEMA Engineering Corporation, Richland, Washington. 
HNF-3580, Rev. 0

Document, Safety Analysis Report for Packaging Onsite Steel Drums, HNF-2209, Waste Management Federal Services, Inc., Northwest Operations for Fluor Daniel Hanford, Inc., Richland, Washington.

Ludowise, J. D., 1978, Radiolytic Gas Evolution in Z-9 Soil Drums, RHO-CD-681, Rockwell Hanford Operations, Richland, Washington.

Morton, R. L., 1982, Inspection of Retrievably Stored Transuranic Waste Containers, SD-WM-TRP-002, Rockwell Hanford Operations, Richland, Washington. 


\section{COGEMA ENGINEERING CORPORATION}

Author

J. A. Demiter

376-9671
Addressee

R. J. Nicklas

WMFS
Letter No.

COGEMA-98-1024

November 11,1998

Subject: HANFORD CONTACT-HANDLED TRANSURANIC DRUM RETRIEVAL PROJECT PLANNING DOCUMENT CONDUCTED UNDER CONTRACT 145, RELEASE 1

\section{DISTRIBUTION}

w/att.

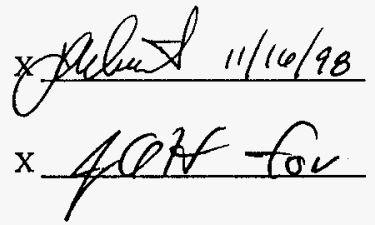

COGEMA Engineering Corporation

J. A. Demiter

H3-26

H3-28

H3-26

H3-26

J. R. Zullo

$\mathbf{X}$

X

x
H3-26

X

Waste Management Federal Services

M. D. Aichele

T4-04

R. R. Ames

T3-07

W. S. Ayers

T4-04

B. M. Barnes

T4-04

L. T. Blackford

T4-05

P. B. Brannan

T4-62

P. J. Crane

T4-04

R. J. Giroir

T4-05

K. L. Hladek

H6-06

D. E. McKenney

H6-06

T. L. Moore

H6-30

K. M. Quigley

H6-06

J. R. Rosser

T4-03

B1 -07

H2-53

Central Files

DOE Reading Room 